\title{
Dendritic Calcium Signaling Triggered by Spontaneous and Sensory-Evoked Climbing Fiber Input to Cerebellar Purkinje Cells In Vivo
}

\author{
Kazuo Kitamura ${ }^{1,2}$ and Michael Häusser ${ }^{1}$ \\ ${ }^{1}$ Wolfson Institute for Biomedical Research and Department of Neuroscience, Physiology, and Pharmacology, University College London, Gower Street, \\ London WC1E 6BT, United Kingdom, and 2Department of Neurophysiology, Graduate School of Medicine, University of Tokyo, Bunkyo-ku, Tokyo \\ 113-0033, Japan
}

Cerebellar Purkinje cells have one of the most elaborate dendritic trees in the mammalian CNS, receiving excitatory synaptic input from a single climbing fiber $(\mathrm{CF})$ and from $\sim 200,000$ parallel fibers. The dendritic $\mathrm{Ca}^{2+}$ signals triggered by activation of these inputs are crucial for the induction of synaptic plasticity at both of these synaptic connections. We have investigated $\mathrm{Ca}^{2+}$ signaling in Purkinje cell dendrites in vivo by combining targeted somatic or dendritic patch-clamp recording with simultaneous two-photon microscopy. Both spontaneous and sensory-evoked CF inputs triggered widespread $\mathrm{Ca}^{2+}$ signals throughout the dendritic tree that were detectable even in individual spines of the most distal spiny branchlets receiving parallel fiber input. The amplitude of these $\mathrm{Ca}^{2+}$ signals depended on dendritic location and could be modulated by membrane potential, reflecting modulation of dendritic spikes triggered by the CF input. Furthermore, the variability of CF-triggered $\mathrm{Ca}^{2+}$ signals was regulated by GABAergic synaptic input. These results indicate that dendritic $\mathrm{Ca}^{2+}$ signals triggered by sensory-evoked CF input can act as associative signals for synaptic plasticity in Purkinje cells in vivo and may differentially modulate plasticity at parallel fiber synapses depending on the location of synapses, firing state of the Purkinje cell, and ongoing GABAergic synaptic input.

\section{Introduction}

Purkinje cells exhibit a rich repertoire of dendritic excitability (Llinás and Sugimori, 1980b). Most remarkable are the prominent dendritic $\mathrm{Ca}^{2+}$ spikes, which have been shown in slice preparations to be associated with substantial elevations in dendritic $\left[\mathrm{Ca}^{2+}\right]$ (Tank et al., 1988; Lev-Ram et al., 1992; Miyakawa et al., 1992). Dendritic $\mathrm{Ca}^{2+}$ spikes and their associated $\mathrm{Ca}^{2+}$ signals can be triggered by current injection and by both climbing fiber (CF) and parallel fiber synaptic inputs. While the CF forms hundreds of synaptic contacts along the proximal dendritic tree of Purkinje cells, activation of CF input has been shown to trigger $\mathrm{Ca}^{2+}$ influx, which is detectable throughout the entire dendritic tree (Konnerth et al., 1992; Miyakawa et al., 1992). On the other hand, activation of parallel fibers triggers local dendritic $\left[\mathrm{Ca}^{2+}\right]$

Received May 17, 2010; revised April 27, 2011; accepted May 19, 2011.

Author contributions: K.K. and M.H. designed research; K.K. and M.H. performed research; K.K. and M.H. analyzed data; K.K. and M.H. wrote the paper.

This work was supported by grants from the Wellcome Trust, European Research Council, the Gatsby Charitable Foundation (M. H.), Japan Society for the Promotion of Science Grants-in-Aid for Scientific Research no.22680031 and no. 22650083 (K.K.), Precursory Research for Embryonic Science and Technology (PRESTO) (K.K.), and the Strategic Research Program for Brain Sciences. We thank Karel Svoboda for performing preliminary experiments; Spencer Smith, Christian Wilms, Jenny Davie, Séverine Mahon, Arnd Roth, Benjamin Judkewitz, and Jesper Sjöström for helpful discussions, Taro Ishikawa for analysis tools; and Latha Ramakrishnan for technical assistance. K. K. thanks Masanobu Kano for his support.

Correspondence should be addressed to either Michael Häusser or Kazuo Kitamura, Wolfson Institute for Biomedical Research, University College London, Gower Street, London WC1E 6BT, UK, E-mail: m.hausser@ucl.ac.uk or kkitamura@m.u-tokyo.ac.jp.

DOI:10.1523/JNEUROSCI.2525-10.2011

Copyright $\odot 2011$ the authors $\quad 0270-6474 / 11 / 3110847-12 \$ 15.00 / 0$ increases, which can be confined to small regions of the spiny branchlets (Eilers et al., 1995; Hartell, 1996; Wang et al., 2000; Brenowitz and Regehr, 2005). Dendritic $\left[\mathrm{Ca}^{2+}\right]$ increases triggered by $\mathrm{CF}$ and parallel fiber activity summate nonlinearly, depending upon the timing between these two inputs, and this supralinear summation of $\mathrm{Ca}^{2+}$ signals is thought to play a key role in the induction of short- and long-term synaptic plasticity at parallel fiber synapses (Sakurai, 1990; Konnerth et al., 1992; Miyata et al., 2000; Wang et al., 2000; Coesmans et al., 2004; Brenowitz and Regehr, 2005; Rancz and Häusser, 2006). Accordingly, the CF signal has been proposed to act as a global signal integrating and controlling parallel fiber signals and their plasticity (Ito, 1984). The $\mathrm{Ca}^{2+}$ signal triggered by CF input has also been shown to be crucial for long-term synaptic plasticity at CF synapses (Hansel and Linden, 2000; Weber et al., 2003).

Although CF-evoked dendritic $\mathrm{Ca}^{2+}$ signals have been detected in vivo using bulk loading or electroporation of $\left[\mathrm{Ca}^{2+}\right]$ indicators into Purkinje cells (Sullivan et al., 2005; Mukamel et al., 2009; Ozden et al., 2009; Schultz et al., 2009; Chen et al., 2010), quantitative characterization of the magnitude and spatial spread of the $\mathrm{Ca}^{2+}$ signals and their precise relationship with electrical activity has thus far only been possible in vitro (Konnerth et al., 1992; Miyakawa et al., 1992; Wang et al., 2000). It is crucial to obtain this information in vivo, particularly given that dendritic excitability can be modulated by action potential firing, background excitatory and inhibitory synaptic input, and activity in neuromodulatory afferents. In cortical pyramidal cells, in vivo two-photon imaging has shown that dendritic $\mathrm{Ca}^{2+}$ signaling is 
modulated by background synaptic inputs and by activation of neuromodulatory afferents via sensory stimulation (Svoboda et al., 1997; Helmchen et al., 1999; Svoboda et al., 1999; Waters and Helmchen, 2004; Murayama et al., 2009).

To understand the functional properties of CF-triggered calcium signals in cerebellar Purkinje cells in the intact brain, we used somatic and dendritic patch-clamp recording together with simultaneous two-photon, laser-scanning microscopy in anesthetized rats (Waters et al., 2003; Waters and Helmchen, 2004). This approach allowed us to directly correlate electrophysiological and calcium signaling in the dendrites of cerebellar Purkinje cells in vivo. We show that both spontaneous and sensory-evoked $\mathrm{CF}$ inputs trigger an extensive $\left[\mathrm{Ca}^{2+}\right]$ signal across the entire dendritic tree and that this $\mathrm{Ca}^{2+}$ electrogenesis is modulated by membrane potential, firing state, dendritic location, and ongoing GABAergic synaptic input.

\section{Materials and Methods}

The care of animals and experimental procedures were carried out in accordance with national and institutional guidelines.

Surgery. Sprague Dawley rats (postnatal days 18-26) were anesthetized by intraperitoneal injection of ketamine/xylazine $(80 / 5 \mathrm{mg} / \mathrm{kg}$, Sigma-Aldrich) or inhalation of $0.5-1 \%$ isoflurane in pure $\mathrm{O}_{2}$. Depth of anesthesia was monitored regularly by observing whisker movements and the pinch withdrawal reflex of the hindlimb; additional doses of anesthetic were given as needed. Body temperature was monitored using a rectal temperature probe and maintained at $37 \pm 1{ }^{\circ} \mathrm{C}$ using a heating pad (FHC). The rat was fixed on a custom stereotaxic apparatus under a surgical microscope (MZ6, Leica). The skull over the cerebellum was exposed and a stainless steel frame was glued to it with superglue and dental cement. A small craniotomy $(\sim 2 \mathrm{~mm})$ was made to expose cerebellar vermis or folium Crus IIa $(\sim 4-5 \mathrm{~mm}$ lateral and $1.5-2 \mathrm{~mm}$ posterior to the occipital bone line). The dura was carefully removed, and the craniotomy was filled with 1.5-2\% agarose (type IIIa, Sigma-Aldrich) in solution containing the following (in $\mathrm{mM}$ ): $150 \mathrm{NaCl}, 2.5 \mathrm{KCl}, 10 \mathrm{HEPES}$, $2 \mathrm{CaCl}_{2}, 1 \mathrm{MgCl}_{2}, \mathrm{pH}$ 7.3. A coverslip was placed over the agarose to minimize brain movements. The rat was then transferred to the animal stage under the two-photon microscope.

In vivo patch-clamp recording. Single whole-cell patch-clamp recordings from Purkinje cell somata or dendrites in vivo were obtained using the "blind" approach as described previously (Margrie et al., 2002; Loewenstein et al., 2005). Alternatively, patch-clamp recordings were made under direct visual control from negatively stained Purkinje cell somata using two-photon microscopy ("shadowpatching") (Kitamura et al., 2008), as follows. The patch pipette was tip filled with the internal solution (see below, this paragraph) containing $50 \mu \mathrm{M}$ Alexa Fluor 594 but without $\left[\mathrm{Ca}^{2+}\right]$ indicator. By applying brief positive pressure to the pipette, the extracellular space was filled with dye, and Purkinje cell somata were identified as the "negative image" by their shape, size, and depth. The pipette tip filled with Alexa Fluor 594 was brought to a negatively stained Purkinje cell soma, and the contact of the pipette tip to the cell was monitored by the increase of the tip resistance and confirmed by the formation of a bright, dye-filled "dimple." The positive pressure was then released to make a tight $\mathrm{G} \Omega$ seal, and the whole-cell configuration was established by applying brief suction. The resistance of the recording pipette was 5-7 M $\Omega$, and the pipette internal solution contained the following (in mM): $130 \mathrm{~K}-\mathrm{MeSO}_{3}, 6 \mathrm{NaCl}, 10 \mathrm{HEPES}, 2 \mathrm{MgCl}_{2}, 4$ $\mathrm{Na}_{2} \mathrm{ATP}, 0.5 \mathrm{Na}_{2} \mathrm{GTP}$, 0.5 Fluo-4 [or 0.2-0.3 Oregon Green 488 BAPTA-1 (OGB-1)], and 0.05 Alexa Fluor 594, pH 7.3 (290 mOsm). The concentration of $\mathrm{Ca}^{2+}$ indicators used could counteract native $\mathrm{Ca}^{2+}$ buffers (0.2-0.4 mM) (Maeda et al., 1999). All fluorescent dyes were from Invitrogen. Recordings were made using a MultiClamp 700A amplifier (Molecular Devices), and were filtered at $10 \mathrm{kHz}$ and digitized at $20-50$ $\mathrm{kHz}$ using a Digidata 1322A (Axon) controlled by AxoGraph X software (AxoGraph Scientific). Sensory responses were evoked by delivering an airpuff (50 ms, 40-50 psi; Picospritzer III, General Valve) to the ipsilateral perioral surface. The duration of experiments was $\sim 5-6 \mathrm{~h}$, including initial surgery. During recordings, viability of animals was checked regularly by monitoring respiratory rate $(\sim 60-120 / \mathrm{min})$ by visual inspection.

In vivo two-photon calcium imaging. In vivo two-photon imaging (Denk et al., 1990; Svoboda et al., 1997) was performed using a twophoton laser-scanning microscope (In Vivo Imager, Prairie Technologies). A mode-locked Ti:sapphire laser (MaiTai, Spectra Physics) was used for two-photon excitation $(\sim 100 \mathrm{fs}$ pulse width and $80 \mathrm{MHz}$ repetition rate; center wavelength, $800-810 \mathrm{~nm}$ ) in conjunction with a waterimmersion objective lens (LUMPlan $40 \times / \mathrm{W} / \mathrm{IR} 2$ or $60 \times / \mathrm{W} / \mathrm{IR} 2$, Olympus). Average laser power at the sample was $<20 \mathrm{~mW}$ (mostly 5-10 $\mathrm{mW}$ ). Fluorescence from Fluo-4 (or OGB-1) and Alexa Fluor 594 was divided into green and red channels by a dichroic mirror (575DCXR, Chroma) and detected by photomultiplier tubes (R3896, Hamamatsu). Stray light from the excitation laser and background fluorescence was eliminated by a short-pass filter (E650SP-2P, Chroma) and emission filters (BGG22 for green; HQ607/45 for red, Chroma). Image acquisition and microscope positioning was controlled by ScanImage (Pologruto et al., 2003) or PrairieView (Prairie Technologies) software. Dendritic $\left[\mathrm{Ca}^{2+}\right]$ transients were recorded in line scan mode at $2 \mathrm{~ms} /$ line. Calcium imaging was performed at least $45 \mathrm{~min}$ after break-in to allow equilibration of the dye in the dendritic tree. Dendritic calcium imaging following electroporation of the indicator dye was performed as described previously (Nevian and Helmchen, 2007; Kitamura et al., 2008). OGB-1 (1 mm in internal solution) was loaded by electroporation using a hyperpolarizing current pulse $(-200 \mathrm{nA}, 50 \mathrm{~ms})$ with the pipette positioned on the cell soma. Calcium imaging was performed $\sim 60$ min after electroporation.

Analysis. All electrophysiological data and $\left[\mathrm{Ca}^{2+}\right]$ transients were analyzed using Igor Pro (WaveMetrics), MATLAB (MathWorks), and AxoGraph X. To measure amplitude, rise time and instantaneous frequency, simple and complex spikes were detected by fitting to the template waveform taken from the same trace by using the event detection function of AxoGraph X. Up and down states of the membrane potential of Purkinje cells were detected as described previously (Loewenstein et al., 2005). Detection of $\left[\mathrm{Ca}^{2+}\right]$ transients was triggered by the onset of complex spikes measured in the electrophysiological recording. Fluorescence signals were averaged over the entire width of the dendrite. $\left[\mathrm{Ca}^{2+}\right]$ transients were calculated as $\Delta G / R=\left(G-G_{0}\right) / R$, the ratio of change in green fluorescence to red fluorescence after subtraction of background fluorescence for Fluo-4 (Yasuda et al., 2003), or $\Delta F / F=\left(F-F_{0}\right) /\left(F_{0}-F_{\mathrm{b}}\right)$, where $F_{0}$ is baseline fluorescence without $\left[\mathrm{Ca}^{2+}\right]$ transients and $F_{\mathrm{b}}$ is background fluorescence next to the dendrite for OGB-1. The peak amplitude of $\left[\mathrm{Ca}^{2+}\right]$ transients was defined as the difference between the baseline [average $\Delta G / R(\Delta F / F)$ for $20 \mathrm{~ms}$ before the onset of complex spike] and the average of five data points around the peak. The $\left[\mathrm{Ca}^{2+}\right]$ transient traces were smoothed with a sliding window of 3-5 points for presentation. Signal-to-noise ratio (peak amplitude divided by standard deviation of baseline noise) ranged 2-8. Variability in the peak amplitude of $\left[\mathrm{Ca}^{2+}\right]$ transients in different dendrites $\left(A_{1}\right.$ and $\left.A_{2}\right)$ was quantified as $2\left|A_{1}-A_{2}\right| /\left(A_{1}+A_{2}\right)$, the same equation used for evaluating the regularity of spike trains ( $\mathrm{CV}_{2}$ ISI) (Holt et al., 1996). Statistical significance of the data was tested by Student's $t$ test unless otherwise noted, and all tests were performed using $R$ (http://www.r-project.org/).

To determine the imaging location in dendritic tree, a reference image was taken and compared to the images in the image stack of the entire dendritic tree taken at the end of the recording. The image stack was processed using a nonlinear anisotropic diffusion filter (Broser et al., 2004) to enhance the signal-to-noise ratio, and the maximum intensity projection of the image was obtained using ImageJ (http://rsb.info.nih.gov/ij/).

\section{Results}

Dendritic and somatic patch-clamp recordings from cerebellar Purkinje cells in vivo

Simultaneous two-photon imaging and whole-cell patch-clamp recordings from Purkinje cells were performed in rats under ketamine/xylazine anesthesia. The cells recorded were morphologi- 

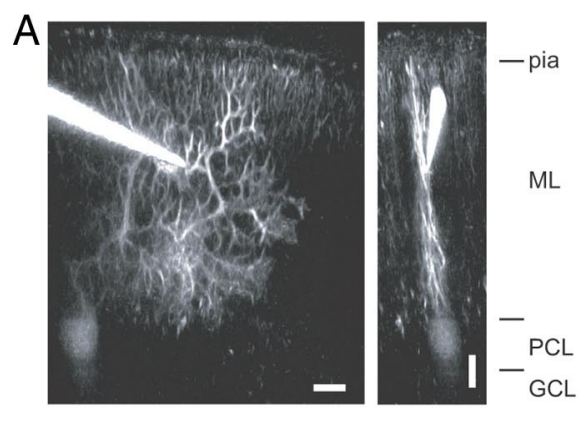

B

dendrite, $150 \mu \mathrm{m}$
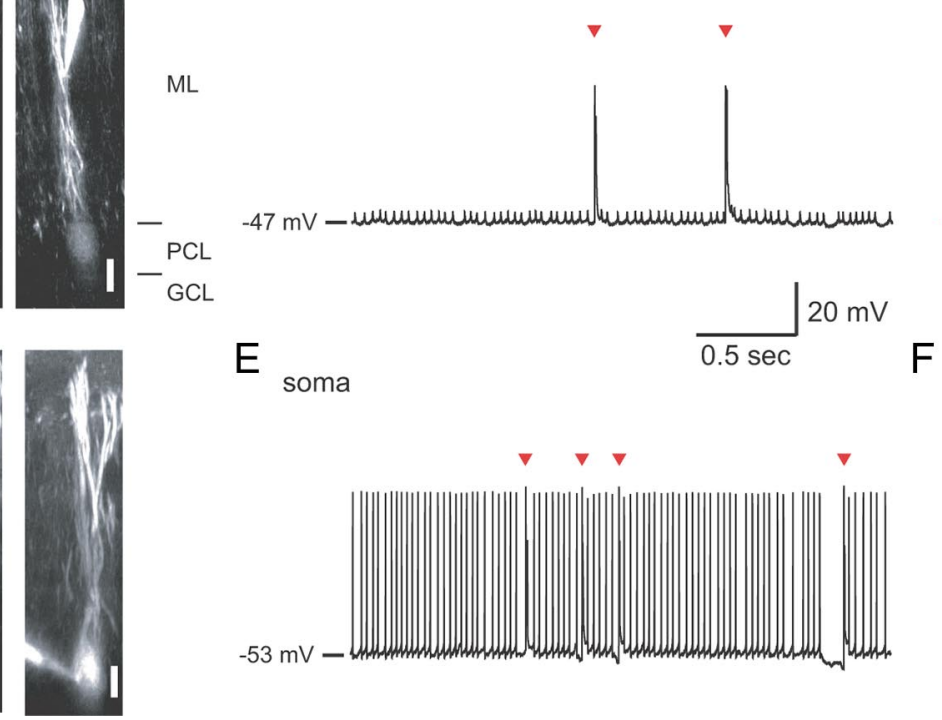

C
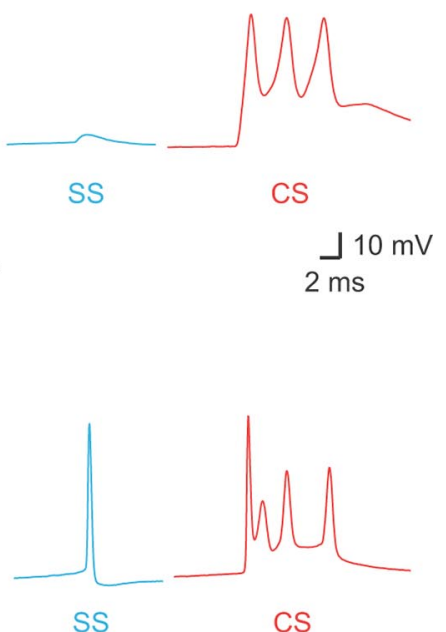

Figure 1. Dendritic and somatic whole-cell recordings from cerebellar Purkinje cells in vivo. A-C, A dendritic whole-cell patch-clamp recording from a cerebellar Purkinje cell ( $\sim 150 \mu \mathrm{m}$ from soma). $A, X Z$ (left) and YZ (right) projections from the two-photon image stack of the filled neuron. The location of the recording in the dendritic tree can be determined precisely from the position of the recording pipette. ML, Molecular layer; PCL, Purkinje cell layer; GCL, granule cell layer. Scale bars, $20 \mu \mathrm{m}$. $\boldsymbol{B}$, Whole-cell patch-clamp recording from the same neuron imaged in $\boldsymbol{A}$. $\boldsymbol{D}-\boldsymbol{F}$, Whole-cell recording at the soma. In both recordings, cells exhibited typical discharge patterns called "simple spike" (SS) and "complex spike" (CS; arrowheads). Note that SS amplitude decreased dramatically at the dendritic recording site $(\boldsymbol{C})$ compared with the soma $(\boldsymbol{F})$. Spike shape also depends on the location of the recording.

cally identified as Purkinje cells via two-photon imaging of the dendritic tree (Fig. 1A,D), as well as by their characteristic electrophysiological properties, in particular a high rate of simple spike (SS) firing $(32 \pm 7.3 \mathrm{~Hz}$, mean \pm SEM, $n=9)$ and the spontaneous occurrence of complex spikes (CSs) at a frequency of $1.5 \pm 0.20 \mathrm{~Hz}$ (Fig. $1 B, E$ ).

Two-photon imaging enabled the precise identification of the recording site, allowing us to analyze the location dependence of electrical signaling in Purkinje cells in vivo (Fig. $1 B, E$ ). Simple spikes were detectable at all dendritic recording sites, and as expected the SS frequency was not different from somatic recordings $(38 \pm 5.2 \mathrm{~Hz}, n=5, p>0.4)$. However, the mean amplitude of SSs at dendritic recording sites was greatly attenuated ( $4.3 \pm$ $0.5 \mathrm{mV} ; 70-150 \mu \mathrm{m}$ from soma, $n=5$ ) (Fig. $1 C$, left), compared to recordings at the soma $(58 \pm 3.4 \mathrm{mV} ; n=4, p<0.001)$ (Fig. $1 F$, left). The rise time of dendritically recorded SSs was also substantially slower compared to the soma $(20-80 \%$ rise time of $1.0 \pm 0.40 \mathrm{~ms}$ compared to $0.16 \pm 0.01 \mathrm{~ms}, p<0.02)$. These results indicate that the $\mathrm{Na}^{+}$action potential exhibits only weak backpropagation into the dendritic tree of Purkinje cells in vivo, consistent with observations in slice preparations (Hounsgaard and Yamamoto, 1979; Llinás and Sugimori, 1980b; Stuart and Häusser, 1994).

CSs were clearly distinguishable at dendritic recording sites (mean frequency, $1.4 \pm 0.34 \mathrm{~Hz}$; not different from somatic recordings; $p>0.5$ ) (Fig. $1 B$ ). However, the amplitude of the prominent first spike in the CS was smaller and its rise time was slower in dendritic recordings (amplitude of $35 \pm 4.3 \mathrm{mV}$ and rise time of $1.5 \pm 0.56 \mathrm{~ms}$ for dendritic recordings vs $59 \pm 7.0 \mathrm{mV}$ and $0.15 \pm 0.010 \mathrm{~ms}$ at the soma, $p<0.04$ and $p<0.02$, respectively) (Fig. 1C,F, right). Presumably, this reflects the fact that the underlying biophysical basis of the CS changes from being primarily $\mathrm{Na}^{+}$channel mediated at the soma to being $\mathrm{Ca}^{2+}$ channel mediated at dendritic locations (Llinás and Sugimori, 1980a,b; Davie et al., 2008).
Dendritic calcium transients evoked by dendritic $\mathrm{Ca}^{2+}$ spikes We next investigated dendritic $\mathrm{Ca}^{2+}$ spikes activated by somatic depolarization of Purkinje cells. Strong depolarizing current pulses were injected via the somatic recording electrode, and their amplitude was increased until the threshold for dendritic $\mathrm{Ca}^{2+}$ spikes was reached (Fig. 2A-C). Dendritic spikes were associated with large $\mathrm{Ca}^{2+}$ signals in both proximal and distal dendrites (Fig. $2 B$ ). In single traces, distinct $\left[\mathrm{Ca}^{2+}\right]$ transients were observed to be time locked to the stereotypic slow-rising dendritic $\mathrm{Ca}^{2+}$ spikes (Llinás and Sugimori, 1980a) recorded at the soma (Fig. 2C, arrows). In contrast, high-frequency trains of simple spikes produced no detectable $\mathrm{Ca}^{2+}$ signals throughout the dendritic tree (Fig. $2 B-D$ ). This observation confirms the weak dendritic back-propagation of simple spikes [Llinás and Sugimori (1980b), their Fig. 1] and shows that no detectable dendritic $\mathrm{Ca}^{2+}$ influx was produced by the back-propagating $\mathrm{Na}^{+}$spike (Lev-Ram et al., 1992). In addition, during current injectionevoked bouts of dendritic spiking, spontaneous CS could be observed in the somatic membrane potential recording. Spontaneous CS-evoked $\left[\mathrm{Ca}^{2+}\right]$ transients were of a similar amplitude even when the dendritic $\left[\mathrm{Ca}^{2+}\right]$ level was already elevated (compare Figs. 2D,3A), indicating that the amplitude of CFtriggered $\left[\mathrm{Ca}^{2+}\right]$ transients is not saturated under our recording conditions (including depth of anesthesia, composition of intracellular solution, $\mathrm{Ca}^{2+}$ indicator used, and the concentration of dye).

\section{Dendritic $\mathrm{Ca}^{2+}$ signals triggered by spontaneous $\mathrm{CF}$ input}

We next characterized in detail the dendritic $\mathrm{Ca}^{2+}$ signals triggered by spontaneous CF input. CF input, as measured by CSs simultaneously recorded at the soma, was associated with large $\left[\mathrm{Ca}^{2+}\right]$ transients over the entire dendritic tree (Fig. $3 A$, a representative trace at a single location). The rise of $\left[\mathrm{Ca}^{2+}\right]$ transients coincided precisely with the onset of the CS measured electrophysiologically, with the $\left[\mathrm{Ca}^{2+}\right]$ transients reaching a peak 


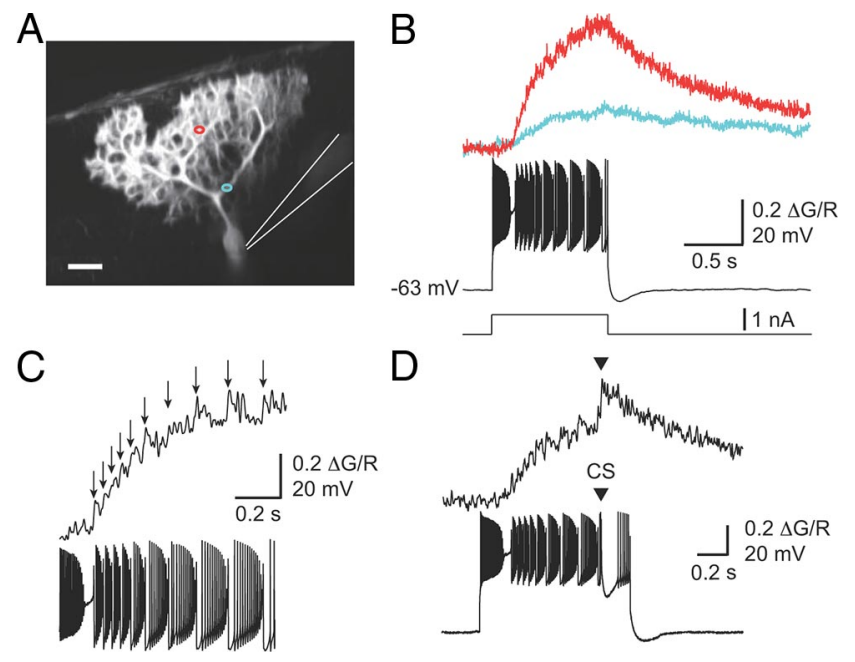

Figure 2. Depolarization-induced $\mathrm{Ca}^{2+}$ spikes and dendritic $\left[\mathrm{Ca}^{2+}\right]$ transients in vivo. $\boldsymbol{A}$, Projection image of the recorded cell. $\left[\mathrm{Ca}^{2+}\right]$ transients were measured at the location indicated by the red ( $\sim 130 \mu \mathrm{m}$ from soma) and cyan ( $\sim 45 \mu \mathrm{m}$ from soma) circles, and whole-cell recording was made at the soma. $\boldsymbol{B}$, Simultaneous recording of dendritic $\left[\mathrm{Ca}^{2+}\right]$ transients (top, average of 10 consecutive trials) and somatic membrane potential (middle, single sweep) in response to a depolarizing current pulse applied via the somatic recording pipette (bottom, $0.9 \mathrm{nA}, 1 \mathrm{~s})$. Red and cyan traces in the top panel are the $\left[\mathrm{Ca}^{2+}\right]$ transients at the locations shown in $\boldsymbol{A}$. $\boldsymbol{C}$, Representative single trace of dendritic $\left[\mathrm{Ca}^{2+}\right]$ transients (top, recorded at the red location in $\boldsymbol{A}$ ) and $\mathrm{Na}^{+}$and $\mathrm{Ca}^{2+}$ spikes recorded at the soma (bottom). Note that individual $\left[\mathrm{Ca}^{2+}\right]$ transients (arrows), corresponding to $\mathrm{Ca}^{2+}$ spikes observed in the electrophysiological recording, were resolved. No dendritic $\left[\mathrm{Ca}^{2+}\right]$ increase was associated with $\mathrm{Na}{ }^{+}$spikes. D, A spontaneous CF-triggered dendritic $\left[\mathrm{Ca}^{2+}\right]$ transient (arrowhead) observed during current injection.

within 2 to $4 \mathrm{~ms}$ (corresponding to 1 to 2 sampling points). This rapid time course indicates that the observed $\mathrm{Ca}^{2+}$ signals were indeed directly triggered by CF activation (Fig. $3 B$ ) and presumably result from the activation of dendritic voltage-gated $\mathrm{Ca}^{2+}$ channels. Across a representative sample of cells, $95.0 \pm 2.1 \%$ of spontaneous $\mathrm{Ca}^{2+}$ signals, detected by thresholding at $2 \mathrm{SD}$ of baseline noise, were precisely linked to a spontaneous CS $(n=4$ cells). This indicates that the vast majority of detected $\left[\mathrm{Ca}^{2+}\right]$ transients under our conditions were linked to spontaneous CF inputs. We rarely observed spontaneous dendritic $\mathrm{Ca}^{2+}$ spikes. Therefore, these results indicate that the spontaneous $\left[\mathrm{Ca}^{2+}\right]$ transients measured under our conditions are attributable primarily to CF activation and not to parallel fiber input or spontaneous $\mathrm{Ca}^{2+}$ spikes.

Each somatically recorded CS was always associated with a dendritic $\left[\mathrm{Ca}^{2+}\right]$ transient; i.e., no failures were observed in the CS-evoked dendritic calcium signal. However, the peak amplitude of the dendritic $\left[\mathrm{Ca}^{2+}\right]$ transients was highly variable from one CS to the next. In the cell shown in Figure $3 A$, the coefficient of variation $(\mathrm{CV})$ of the peak amplitude of $\left[\mathrm{Ca}^{2+}\right]$ transients was 0.4 [population mean CV: $0.34 \pm 0.03, n=5$ ]. What is the origin of this variability? Under our recording conditions, i.e., wholecell recordings under anesthesia, Purkinje cells exhibit bistability in membrane potential (Fig. 3A) (Loewenstein et al., 2005; Tal et al., 2008; Rokni et al., 2009; Yartsev et al., 2009). To investigate the contribution of membrane potential bistability to the CFtriggered $\mathrm{Ca}^{2+}$ signal, we first classified the observed $\left[\mathrm{Ca}^{2+}\right]$ transients depending on whether the CS occurred in the depolarized "up" state (associated with simple spike firing) or in the quiescent, hyperpolarized "down" state (Fig. 3C). In all cells, the peak amplitude of $\left[\mathrm{Ca}^{2+}\right]$ transients in the up state was consistently larger than that in the down state $(n=10 / 10$ cells, $p<$
0.00001). This indicates that the peak amplitude of $\left[\mathrm{Ca}^{2+}\right]$ transients is dependent on the membrane potential of the Purkinje cell at the moment of CF input activation. To quantify this, the peak amplitude of $\left[\mathrm{Ca}^{2+}\right]$ transients was plotted against the membrane potential at the onset of the CS (Fig. 3D). The peak amplitude of $\left[\mathrm{Ca}^{2+}\right]$ transients was larger at more depolarized membrane potentials (Pearson's correlation coefficient $r=0.53$, $p<0.0001)$. On average, the peak amplitude of $\left[\mathrm{Ca}^{2+}\right]$ transients showed a clear correlation with the membrane potential at the onset of the CS (16 dendritic locations in 5 cells) (Fig. 3E).

Since the transition between up and down states is often triggered by CF input (Loewenstein et al., 2005), CF-triggered dendritic $\mathrm{Ca}^{2+}$ signals might play a significant role in regulating the transition. Thus, we further classified the CF-triggered $\left[\mathrm{Ca}^{2+}\right]$ transients into four categories: whether the CF triggered a transition from up to down state, from down to up state, or else produced no transition in either the up and down states. The peak amplitude of the $\left[\mathrm{Ca}^{2+}\right]$ transients was compared between these four cases (Fig. 3F). Confirming the previous observation (Fig. $3 C$ ), the peak amplitude of CF-triggered $\left[\mathrm{Ca}^{2+}\right]$ transients in up state was significantly larger than that in down state $(28$ dendritic locations in 8 cells, $p<0.001)$. Interestingly, we also found that, in up state, the peak amplitude of CF-triggered $\left[\mathrm{Ca}^{2+}\right]$ transients that triggered transitions from up to down state was significantly larger than those that did not trigger transitions $(p<0.003)$. In contrast, in the down state, there was no difference in the peak amplitude of CF-triggered $\left[\mathrm{Ca}^{2+}\right]$ transients, regardless of whether the CS triggered transitions from down to up state or not $(p>0.7)$. These results suggest that larger $\mathrm{Ca}^{2+}$ influx in dendrites in the depolarized up state may play an important role for triggering the transition from up to down states in vivo. We did not observe $\left[\mathrm{Ca}^{2+}\right]$ changes associated with spontaneous up-down or down-up transitions that were not triggered by CS (data not shown). In addition, given that membrane potential bistability of Purkinje cells in physiological (awake) conditions and the role of CS in state transitions are highly debated (Loewenstein et al., 2005; Schonewille et al., 2006; Yartsev et al., 2009), we questioned whether the correlation between peak amplitude of CF-triggered $\left[\mathrm{Ca}^{2+}\right]$ transients and state transitions of the cell is dependent on the depth of anesthesia. We therefore repeated the experiments under relatively light anesthesia $(0.5-1 \%$ isoflurane). As shown in Figure $3 F$, the peak amplitude of CF-triggered $\left[\mathrm{Ca}^{2+}\right]$ transients under light anesthesia fell within the range of those under deep ketamine/xylazine anesthesia and still showed statistically significant differences between up and down states ( $p=0.012,4$ locations in 3 cells). This result implies that the relationship between peak amplitude of CFtriggered $\left[\mathrm{Ca}^{2+}\right]$ transients and state transitions of the cell that we observed may be effective also under more physiological conditions.

Since we measured $\left[\mathrm{Ca}^{2+}\right]$ transients during whole-cell recordings, washout of cytosol may have affected intracellular $\left[\mathrm{Ca}^{2+}\right]$ dynamics. To exclude this possibility, we performed dendritic $\left[\mathrm{Ca}^{2+}\right]$ imaging using single-cell electroporation (supplemental Fig. 1, available at www.jneurosci.org as supplemental material) (Nevian and Helmchen, 2007; Kitamura et al., 2008). The decay time constant of $\left[\mathrm{Ca}^{2+}\right]$ transients measured using this method was comparable to that obtained using whole-cell recordings (single-cell electroporation: $164 \pm 29 \mathrm{~ms}$; whole-cell recordings: $184 \pm 21 \mathrm{~ms} ; n=3$ cells, $p=0.59$ ). As in our wholecell recordings, the amplitude of $\left[\mathrm{Ca}^{2+}\right]$ transients in the up state was significantly larger than that in down state $(p<0.0001)$, 
A

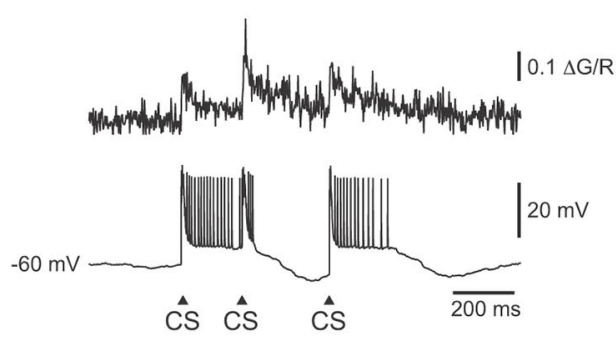

D

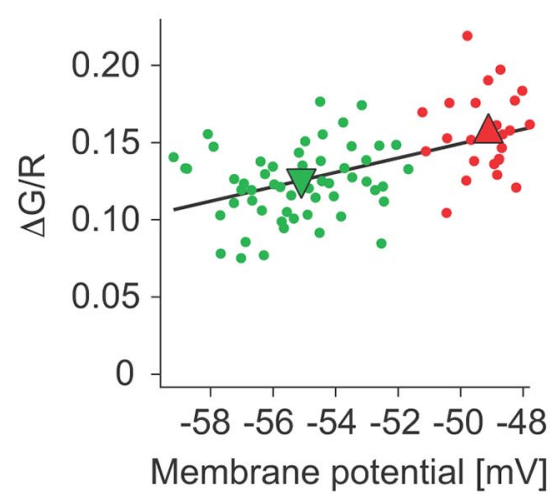

B

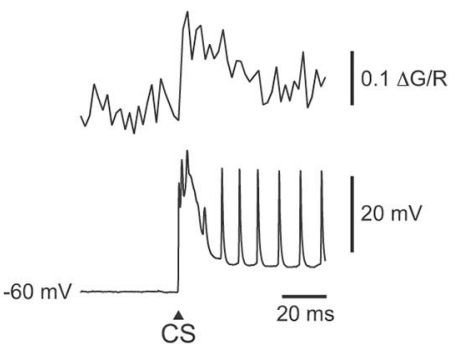

$\mathrm{E}$

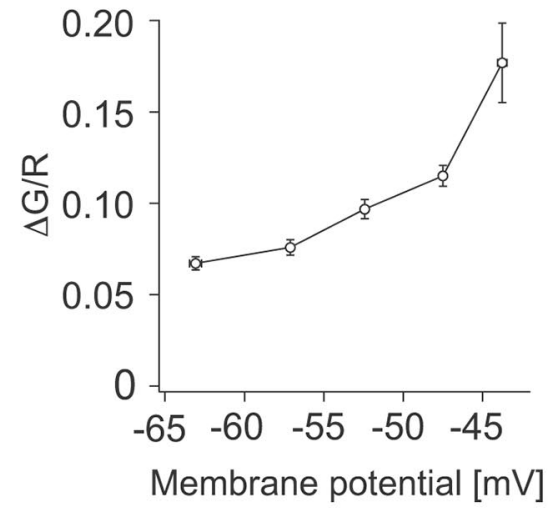

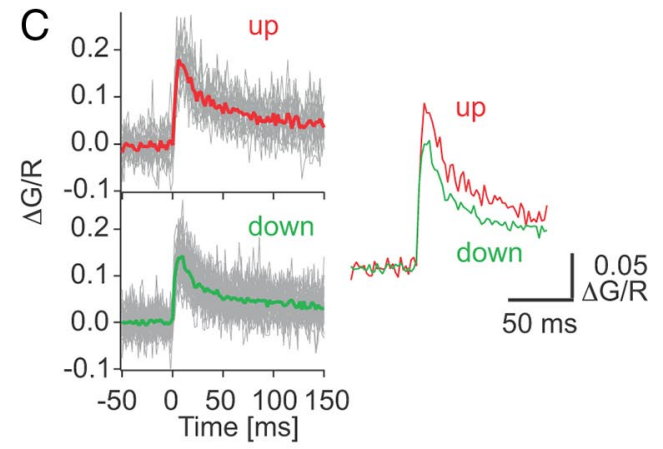

$\mathrm{F}$

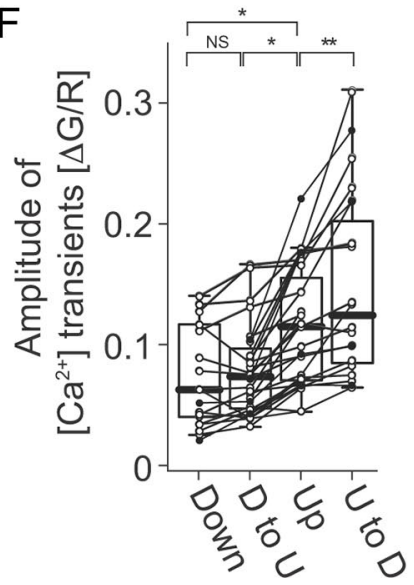

Figure 3. Dendritic $\left[\mathrm{Ca}^{2+}\right]$ transients triggered by spontaneous $C S$ in vivo. $A$, Simultaneous recording of dendritic $\left[\mathrm{Ca}^{2+}\right]$ transients (top, $\sim 65 \mu \mathrm{m}$ from soma) and membrane potential (bottom, perisomatic recording) in response to spontaneous (F inputs (arrowheads). $\boldsymbol{B}$, An example of a single $\left[\mathrm{Ca}^{2+}\right]$ transient on an expanded timescale. The rising phase of dendritic [Ca ${ }^{2+}$ ] transients was precisely timed to the onset of the $\mathrm{CS}$. C, Overlay of dendritic $\left[\mathrm{Ca}^{2+}\right]$ transients in response to multiple spontaneous $\mathrm{CF}$ inputs (gray lines, individual transients; red and green lines, average transients) in depolarized up states (left top, 18 traces) and in hyperpolarized down states (left bottom, 40 traces). Traces were aligned to the onset of CS. Right, 0 verlay of the average traces. $D$, Relationship between amplitude of dendritic $\left[\mathrm{Ca}^{2+}\right]$ transients and the somatic membrane potentials in up states (red circles, individual amplitude; red triangle, average) and in down states (green circles and a green inverted triangle) of the same cell shown in $\boldsymbol{A}-\boldsymbol{C}$. Black line shows linear regression to the individual amplitudes $(r=0.53, p<0.0001)$. $\boldsymbol{E}$, Voltage dependence of the amplitude of dendritic $\left[\mathrm{Ca}^{2+}\right]$ transients. The data were pooled and averaged $(n=7)$. Bars indicate SEM. $\boldsymbol{F}$, Relationship between dendritic $\left[\mathrm{Ca}^{2+}\right]$ transients and state transition under ketamine/xylazine (open circles, 28 dendritic locations in 8 cells; ${ }^{* *} p<0.001,{ }^{*} p<0.003$ ) and under light isoflurane anesthesia (closed circles, 4 locations in 3 cells). U, Up; D, down.

indicating that the effect of washout on CF-triggered $\left[\mathrm{Ca}^{2+}\right]$ transients was negligible.

What is the biophysical origin of the voltage dependence of the CF-triggered $\left[\mathrm{Ca}^{2+}\right]$ transients? In addition to triggering the burst of axonal spikes that form the somatic CS, CF input also triggers dendritic spikes caused by activation of voltage-gated dendritic $\mathrm{Ca}^{2+}$ channels (Fujita, 1968; Llinás and Sugimori, 1980b; Davie et al., 2008). We therefore analyzed the dependence of CF-triggered $\mathrm{Ca}^{2+}$ signals on the number and amplitude of dendritic spikes triggered by CF input (Fig. 4). The peak amplitude of $\left[\mathrm{Ca}^{2+}\right]$ transients was dependent on the number of dendritic spikes in CS and correlated with the dendritic membrane potential (Fig. $4 B, C$ ). In 6 of 8 cells with dendritic recordings ( $4 / 5$ visually identified; $2 / 3$ inferred from electrophysiological signature), we consistently observed more in CS at depolarizing membrane potentials (Spearman's $\rho=0.61, p<10^{-15}$ ) (Fig. 4D). We also observed that the amplitude of the second spikelet in CS was larger at more depolarized membrane potentials $(\rho=0.64, p<$ $10^{-15}$ ) (Fig. $4 D$ ), indicating that larger $\left[\mathrm{Ca}^{2+}\right]$ transients at depolarized membrane potentials are associated with the enhancement of dendritic $\mathrm{Ca}^{2+}$ spikes (Chan et al., 1989). In contrast, the amplitude of the first prominent spike in CS was smaller at depolarizing membrane potentials (data not shown). This is presumably due to reduced synaptic driving force at depolarizing membrane potential. These results indicate that the amount of $\mathrm{Ca}^{2+}$ influx is directly linked to the additional spikelets in CS.

\section{Spatial profile and location dependence of CF-triggered dendritic $\mathrm{Ca}^{2+}$ signals in dendrites}

To determine the spatial profile of CF-triggered $\mathrm{Ca}^{2+}$ signals in dendrites, $\left[\mathrm{Ca}^{2+}\right]$ transients were measured using line scans at various locations in the dendritic tree (Fig. $5 A$ ). The peak amplitude of $\left[\mathrm{Ca}^{2+}\right]$ transients was plotted as a function of the distance from soma ( $n=8$ cells) (Fig. $5 B)$. In the depolarized up states, $\left[\mathrm{Ca}^{2+}\right]$ transients were dependent on the distance from the soma, being largest in the most distal dendrites and smaller in the more proximal dendrites. In contrast, only weak distance dependence was observed in the hyperpolarized down state. As shown in Figure 3 , the amplitude of $\left[\mathrm{Ca}^{2+}\right]$ transients was also dependent on the membrane potential of the cell. We therefore plotted the average peak amplitude of $\left[\mathrm{Ca}^{2+}\right]$ transients against both membrane potential and distance from soma (supplemental Fig. 2, available at www.jneurosci.org as supplemental material). The plot clearly showed both membrane potential and location dependence of the $\left[\mathrm{Ca}^{2+}\right]$ transients, i.e., larger $\mathrm{Ca}^{2+}$ signals in more distal dendrites and more depolarized membrane potentials.

In some cases it was possible to image $\left[\mathrm{Ca}^{2+}\right]$ transients in dendritic spines in the most distal dendrites of the Purkinje cells, the terminal spiny branchlets (Fig. 6) (supplemental movie 1, available at www.jneurosci.org as supplemental material). Large, rapidly rising $\left[\mathrm{Ca}^{2+}\right]$ transients were observed in these parallel fiber spines, which were precisely linked to CF inputs measured 
electrophysiologically at the soma. This result suggests that the CS is associated with a depolarization that spreads throughout the entire dendritic tree of the Purkinje cell and is large enough to activate voltage-gated $\mathrm{Ca}^{2+}$ channels and trigger $\left[\mathrm{Ca}^{2+}\right]$ transients even in the most remote parallel fiber spines on distal terminal branches. The $\left[\mathrm{Ca}^{2+}\right]$ transients in parallel fiber spines were larger in peak amplitude $(0.26 \pm 0.06 \Delta \mathrm{G} / \mathrm{R})$ and decayed faster $(179 \pm 24 \mathrm{~ms})$ than those in dendrites $(0.17 \pm 0.05 \Delta \mathrm{G} / \mathrm{R}$ and $254 \pm$ $36 \mathrm{~ms}, 12$ spines in 5 cells), consistent with the larger surface-to-volume ratio and smaller volume of spines, respectively.

\section{Variability of $\left[\mathrm{Ca}^{2+}\right]$ transients at different dendritic locations is controlled by GABAergic inputs}

Given the highly elaborate structure of the Purkinje cell dendritic tree, we investigated the possibility of differential CF-triggered $\mathrm{Ca}^{2+}$ signals in different branches. CF-triggered $\left[\mathrm{Ca}^{2+}\right]$ transients in different dendritic branches of the same Purkinje cell were imaged simultaneously using line scans at low magnification (Fig. $7 A-D)$. Across distal dendritic branches $(\sim 100 \mu \mathrm{m}$ from soma) emerging from different proximal trunks, we observed a similar pattern of $\left[\mathrm{Ca}^{2+}\right]$ transients (Fig. $7 B)$. The occurrence of CF-triggered $\left[\mathrm{Ca}^{2+}\right]$ transients in different branches was perfectly synchronized in all cells examined $(n=9$ cells), and the peak amplitudes across different branches were correlated $(r=0.27-0.47, p<0.035)$ (Fig. 7C). Thus, there are no failures of CF-evoked dendritic $\left[\mathrm{Ca}^{2+}\right]$ transients, which again is consistent with the reliable propagation of the CS into the whole dendritic tree. However, we found that the peak amplitude between different branches showed considerable variability (Fig. $7 D$ ), suggesting that the amount of $\mathrm{Ca}^{2+}$ influx is locally modulated in different branches.

$\mathrm{CF}$-triggered $\left[\mathrm{Ca}^{2+}\right]$ transients have been shown to be regulated locally by inhibitory synaptic inputs from molecular layer interneurons (Callaway et al., 1995). To clarify whether the variability of $\left[\mathrm{Ca}^{2+}\right]$ transients we observed in vivo was caused by interaction with inhibitory synaptic input in vivo, we measured CF-triggered $\mathrm{Ca}^{2+}$ transients in the presence of the blockers of GABAergic synaptic transmission (50 $\mu \mathrm{M}$ SR95531 and $50 \mu \mathrm{M}$ CGP52432) (Fig. 8). Application of these blockers increased SS frequency from $34.3 \pm 10.5 \mathrm{~Hz}$ to $61.7 \pm 15.8 \mathrm{~Hz}(n=3$ cells, $p=$ $0.036)$ as expected from block of tonic, ongoing GABAergic inhibition to Purkinje cells (Miyashita and Nagao, 1984; Jaeger and Bower, 1994; Häusser and Clark, 1997). The branch-to-branch variability of the peak amplitude of $\left[\mathrm{Ca}^{2+}\right]$ transients was reduced by blocking inhibitory inputs (Fig. 8C,D). In all cells examined, branch-to-branch variability was consistently decreased by application of GABA blockers in both up and down states ( $p=$ 0.019 ) (Fig. $8 E$ ). We also found that CV of the peak amplitude of $\left[\mathrm{Ca}^{2+}\right]$ transients in individual dendrites was reduced by appli-
B
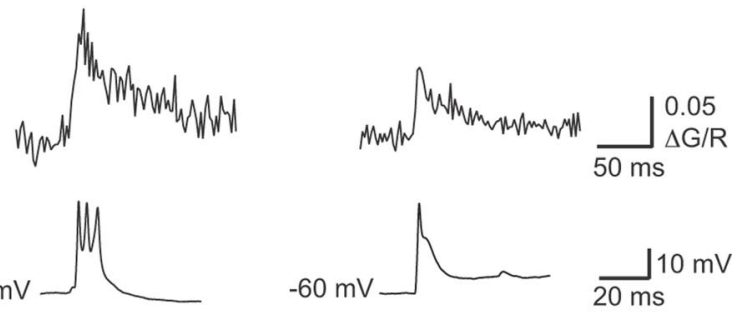

D

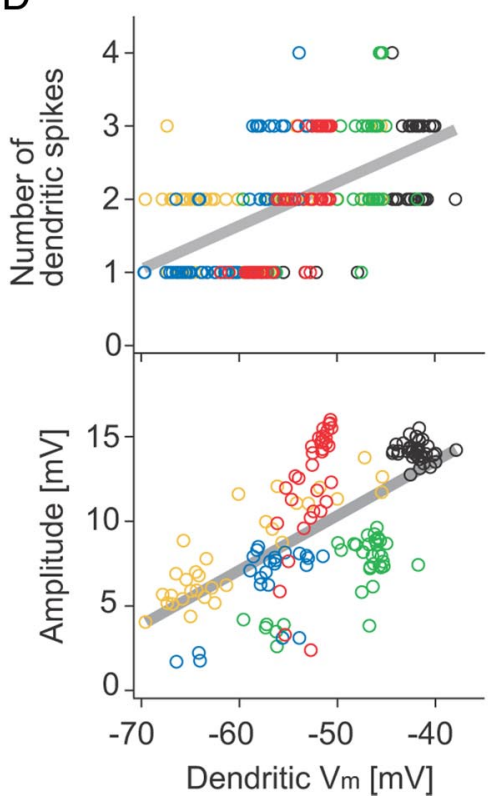

Dendritic $\mathrm{Vm}[\mathrm{mV}]$

Dendritic Vm [mV]

Figure 4. Modulation of dendritic spikes underlies voltage dependence of dendritic $\left[\mathrm{Ca}^{2+}\right]$ transients. $\boldsymbol{A}$, Dendritic $\left[\mathrm{Ca}^{2+}\right]$ transients were analyzed at close proximity to the dendritic recording site ( $~ 150 \mu \mathrm{m}$ from soma; linescan at yellow bar). Scale bar, $10 \mu \mathrm{m}$. B, Dendritically recorded CSs (bottom) and corresponding dendritic [ $\left.\mathrm{Ca}^{2+}\right]$ transients (top, average of 12 (left) and 32 (top) and the amplitude of second spikes (bottom) in dendritically recorded CSs (70-150 $\mu \mathrm{m}$ from soma, $n=$ 5). Colors show the data from different cells. Zero amplitude, i.e., only one spike in the CS, was excluded. Gray lines show linear fit to the data (Spearman's $\rho$ is 0.61 for spike number and 0.64 for spike amplitude, $p<10^{-15}$ ). Note that enhancement of dendritic $\left[\mathrm{Ca}^{2+}\right]$ transients at depolarized membrane potentials is directly associated with the enhancement of dendritic $\mathrm{Ca}^{2+}$ spikes.

cation of GABA blockers ( $p=0.016$ ) (Fig. $8 F$ ), indicating that branch-to-branch variability in control conditions arises from the variability in individual branches that is controlled by GABAergic inhibition.

\section{Sensory-evoked CF signals}

To investigate sensory-evoked dendritic CF signaling, we made recordings from Purkinje cells in folium Crus IIa, which receives tactile input from the perioral region (Bower and Woolston, 1983; Llinás and Sasaki, 1989). Sensory stimulation, which was delivered to the ipsilateral perioral surface via brief airpuffs, evoked CF inputs (Fig. $9 A, C$ ). On average, $42 \pm 1 \%$ of the trials evoked CSs with a latency of $78 \pm 3 \mathrm{~ms}$ from the onset of the sensory stimulus ( $n=5)$, comparable to previous studies (Brown and Bower, 2001; Loewenstein et al., 2005). Sensory-evoked CF input was also associated with substantial dendritic $\left[\mathrm{Ca}^{2+}\right]$ signals (Fig. $9 B, D$ ), as observed in response to spontaneous $\mathrm{CF}$ inputs. We did not observe detectable $\left[\mathrm{Ca}^{2+}\right]$ increases when sensory stimuli did not evoke CSs (Fig. 9D), indicating that the observed $\left[\mathrm{Ca}^{2+}\right]$ transients were attributable primarily or solely to sensory-evoked CF inputs.

Because we recorded from the region Crus IIa, which shows a comparable pattern of CF and mossy fiber tactile projections 

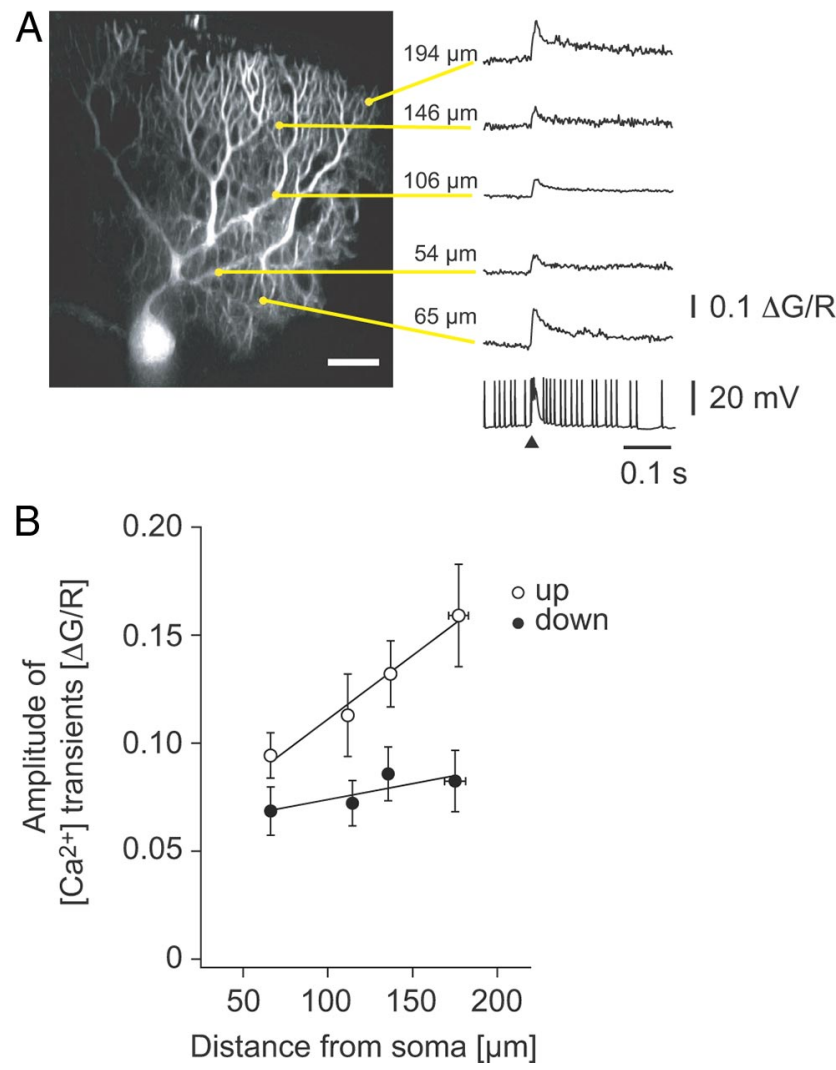

Figure 5. Spatial profile of dendritic $\mathrm{Ca}^{2+}$ influx triggered by spontaneous $\mathrm{CF}$ input. $\mathrm{A}, \mathrm{An}$ example of $\left[\mathrm{Ca}^{2+}\right]$ transients at various dendritic locations in the same Purkinje cell. All $\left[\mathrm{Ca}^{2+}\right]$ transients measured were aligned to the onset of $\mathrm{CS}$ (bottom trace, arrowhead) and averaged. At each location the distance from soma is given. $\boldsymbol{B}$, Relationship between amplitude of dendritic $\left[\mathrm{Ca}^{2+}\right]$ transients and the distance from soma $(n=8) . \mathrm{Ca}^{2+}$ influx in the depolarized up state is enhanced in distal dendrites compared with proximal dendritic regions.

(Brown and Bower, 2001), the stimuli often activated the mossy fiber-granule cell-parallel fiber (and inhibitory interneuron) pathway as well as CF input. A representative example of sensoryevoked responses is shown in Figure 9E, where sensory stimulation either evoked SS firing or EPSPs followed by inhibitory responses, with both responses often being followed by a CS. Thus, sensory-evoked parallel fiber (and inhibitory) inputs might modulate the $\mathrm{CF}$ triggered $\left[\mathrm{Ca}^{2+}\right]$ transients, and we therefore compared sensory-evoked and spontaneous $\left[\mathrm{Ca}^{2+}\right]$ transients at various dendritic locations. However, sensory-evoked CF inputs triggered $\left[\mathrm{Ca}^{2+}\right]$ transients of similar amplitude to that of spontaneous CF inputs (Fig. 9F). Across cells, we did not observe a significant difference between spontaneous and sensory-evoked CF-evoked $\left[\mathrm{Ca}^{2+}\right]$ signals ( $p=0.14$, two-way ANOVA; 9 dendritic locations in 3 cells) (Fig. $9 F$ ). We did observe a statistically significant increase in CF-evoked $\mathrm{Ca}^{2+}$ signals between up and down states $(p=0.036)$ (Fig. $9 F)$, as observed for spontaneous $\mathrm{CF}$-evoked $\mathrm{Ca}^{2+}$ transients (Fig. $3 C, F$ ). This suggests that while there is no global effect of parallel fiber inputs on CF-triggered dendritic $\mathrm{Ca}^{2+}$ signals evoked by the same sensory stimulus, these signals can also be modulated by membrane potential and the firing state of the Purkinje cell.

\section{Discussion}

We investigated dendritic $\mathrm{Ca}^{2+}$ signals triggered by spontaneous and sensory-evoked CF inputs in rat cerebellar Purkinje cells in vivo. Both spontaneous and sensory-evoked CF inputs can trigger

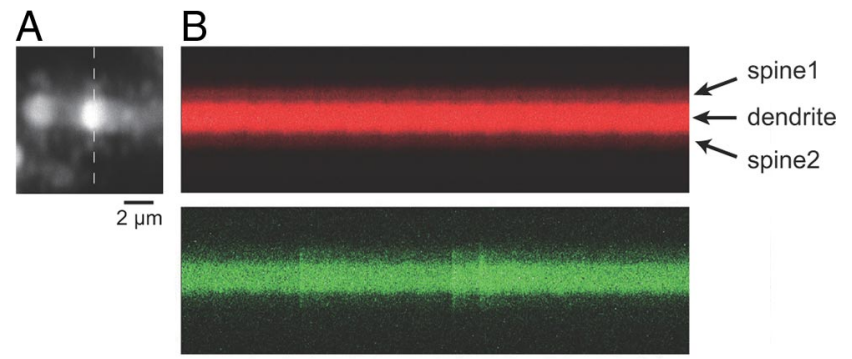

C spine1

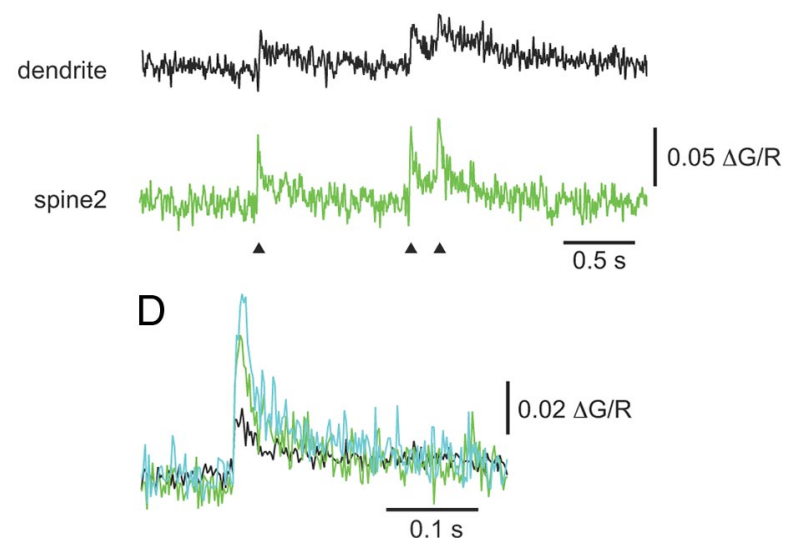

Figure 6. $\left[\mathrm{Ca}^{2+}\right]$ transients triggered by $C F$ input at parallel fiber spines. $A$, Image showing a terminal dendritic branchlet of a Purkinje cell $\sim 140 \mu \mathrm{m}$ from the soma. $\boldsymbol{B}$, The fluorescence change triggered by $C F$ input was measured using a line scan at the position indicated by the broken line in $\boldsymbol{A}$ (top, red channel: Alexa Fluor 594; bottom, green channel: Fluo-4). C, $\left[\mathrm{Ca}^{2+}\right]$ transients in the parent dendrite and individual spines shown in $\boldsymbol{B}$. Spine and dendrite $\mathrm{Ca}^{2+}$ signals were directly linked to CF input simultaneously recorded at the soma (arrowhead). D, Overlay of the $\left[\mathrm{Ca}^{2+}\right]$ transients in the dendrite (black line, average of 9 transients) and in individual spines (cyan and green lines, colors corresponding to the spines in $\mathbf{C}$ ).

global and robust $\left[\mathrm{Ca}^{2+}\right]$ transients across the entire dendritic tree, including in parallel fiber spines on terminal spiny branchlets. The amplitude of these $\mathrm{Ca}^{2+}$ signals can be modulated by state-dependent changes in membrane potential, which we demonstrate is linked to modulation of dendritic spikes triggered by $\mathrm{CF}$ input. We also showed that the amplitude of CF-evoked $\mathrm{Ca}^{2+}$ signals depends on dendritic location and can be locally modulated by GABAergic synaptic transmission. Our findings reveal that the CF-evoked $\mathrm{Ca}^{2+}$ entry represents a global, modulatable dendritic signal in vivo that can play a crucial role in synaptic integration and plasticity in cerebellar Purkinje cells.

\section{Dendritic excitability of Purkinje cells in vivo}

Our ability to precisely localize the recording site using simultaneous two-photon imaging provides the first systematic view of the dendritic physiology of Purkinje cells studied by using in vivo patch-clamp recording. SSs were barely detectable at dendritic recording sites and also did not produce significant dendritic $\left[\mathrm{Ca}^{2+}\right]$ transients even during long trains of SSs, indicating weak back-propagation of $\mathrm{Na}^{+}$spikes into Purkinje cell dendrites. This is consistent with in vitro experiments in Purkinje cells (Llinás and Sugimori, 1980b; Lev-Ram et al., 1992; Stuart and Häusser, 1994) and indicates that the weak, passive backpropagation of SS into Purkinje cell dendrites in vivo is largely attributable to the low dendritic $\mathrm{Na}^{+}$channel density (Stuart and 
Häusser, 1994) and the extensive dendritic branching of Purkinje cell (Vetter et al., 2001). We also show that regenerative dendritic $\mathrm{Ca}^{2+}$ spikes, which trigger substantial dendritic $\mathrm{Ca}^{2+}$ influx, are generally not observed spontaneously in vivo but can be initiated by prolonged, strong current injection, as originally observed in vitro (Llinás and Sugimori, 1980a,b; LevRam et al., 1992; Midtgaard et al., 1993).

In contrast to the barely detectable SSs in Purkinje cell dendrites in vivo, we show that the somatic CS is associated with a large electrical event at dendritic recording sites, resulting from the generation of one or more dendritic $\mathrm{Ca}^{2+}$ spikes. These results agree well with observations in slice preparations (Fujita, 1968; Llinás and Sugimori, 1980b; Davie et al., 2008), indicating that synaptic or neuromodulatory input present in the intact brain does not qualitatively alter CF signaling in vivo. How can CF input generate such a prominent and widespread dendritic depolarization in vivo when even high-frequency SSs have only a minimal effect on dendritic excitability (in striking contrast to pyramidal cells) (Helmchen et al., 1999; Svoboda et al., 1999; Waters et al., 2003)? This is due to the axonal site of SS generation (Stuart and Häusser, 1994; Palmer et al., 2010) and the very narrow half width of SSs $(\sim 0.2 \mathrm{~ms}$ at physiological temperature) (Fig. 1) (Llinás and Sugimori, 1980a; McKay and Turner, 2004)), which are thus heavily filtered by the dendritic tree (Vetter et al., 2001), resulting in dendritic depolarization far below the threshold for regenerative $\mathrm{Ca}^{2+}$ spikes, even with high-frequency firing. In contrast, the widespread distribution of CF input across the proximal dendrites of Purkinje cells (Palay and Chan-Palay, 1974) allows this input to overcome the massive capacitive load of the dendrites (Vetter et al., 2001; Bekkers and Häusser, 2007) and produce a widespread depolarization beyond threshold for $\mathrm{Ca}^{2+}$ spike generation, even under in vivo conditions.

\section{Dendritic $\mathrm{Ca}^{2+}$ signals triggered by $\mathrm{CF}$ input}

Somatic CSs recorded electrophysiologically were always associated with dendritic $\mathrm{Ca}^{2+}$ signals throughout the dendritic tree of Purkinje cells. These $\mathrm{Ca}^{2+}$ signals were precisely time locked to the CS, rose within milliseconds even in the most distal spiny branchlets, and decayed with a single time constant of several hundred milliseconds. This suggests that the $\left[\mathrm{Ca}^{2+}\right]$ transients observed are attributable to the influx of $\mathrm{Ca}^{2+}$ through direct activation of voltage-gated $\mathrm{Ca}^{2+}$ channels opened by the dendritic spikes activated by CF synaptic inputs and confirms that SSs do not produce detectable dendritic $\left[\mathrm{Ca}^{2+}\right]$ transients even at high frequencies (Lev-Ram et al., 1992). The lack of a prominent slow component of the $\mathrm{Ca}^{2+}$ signal, e.g., driven by mGluR activation (Takechi et al., 1998; Dzubay and Otis, 2002), suggests that $\mathrm{Ca}^{2+}$ release from internal stores does not make a major contribution to the observed CF-evoked $\mathrm{Ca}^{2+}$ signals, although further ity $\left.=2\left|A_{1}-A_{2}\right| /\left(A_{1}+A_{2}\right)\right]$.

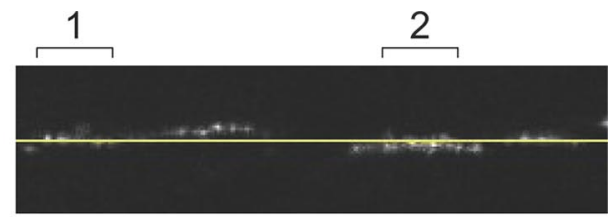

C

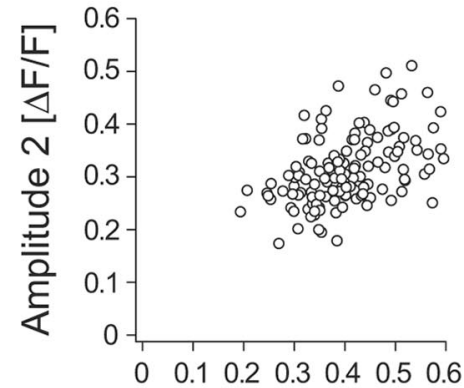

Amplitude $1[\Delta \mathrm{F} / \mathrm{F}]$

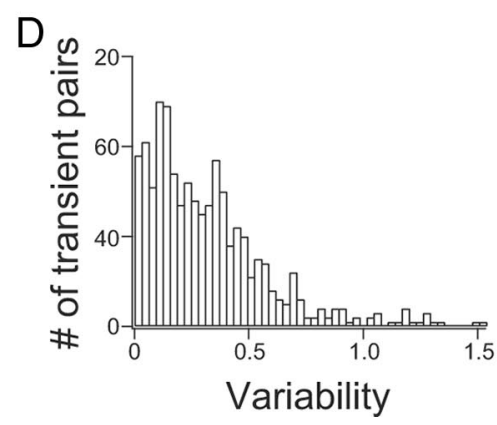

Figure 7. Spread of the $\mathrm{CF}$-triggered $\left[\mathrm{Ca}^{2+}\right]$ transients in distal dendrites in vivo. $A,\left[\mathrm{Ca}^{2+}\right]$ transients in different dendritic Occurrence of $C S$ was simultaneously recorded at soma and is shown by arrowheads. Note that each dendritic region analyzed

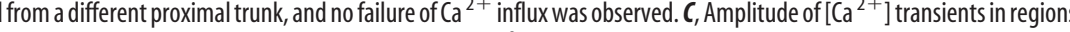
and 2 shown in $\boldsymbol{B}$. Correlation coefficient, $r=0.48\left(p<10^{-9}\right)$. $\boldsymbol{D}$, Trial-to-trial variation in amplitude variability with time; shown is an overall histogram of the difference of the peak amplitude of $\left[\mathrm{Ca}^{2+}\right]$ transients between different branches [variabil-

study is required to investigate this phenomenon quantitatively in vivo.

The mean amplitude of the dendritic $\left[\mathrm{Ca}^{2+}\right]$ transients was dependent on the location in the dendritic tree, being larger in more distal dendrites, particularly in the up state. The origin of this location dependence is primarily caused by surface-tovolume effects, producing larger $\left[\mathrm{Ca}^{2+}\right]$ transients in thinner dendrites at distal branches (Lev-Ram et al., 1992). An alternative possibility is that it may reflect nonuniform dendritic distribution of $\mathrm{Ca}^{2+}$ channels, which are known to be present in the spiny branchlets (Denk et al., 1995; Kulik et al., 2004; Isope and Murphy, 2005). Alternatively, the gradient of the $\mathrm{Ca}^{2+}$ signal may reflect a nonuniform profile of dendritic voltage; both passive and active dendritic properties would be expected to show an "end effect" such that dendritic voltage would increase progressively as it spreads into the terminal dendritic branches, or the nonuniform membrane potential could be caused by a gradient of background excitatory synaptic input increasing toward distal dendrites. The latter mechanisms (nonuniform Ca channel distribution and dendritic voltage) may explain the larger effect in up states.

Our findings show directly that CF input evokes large $\mathrm{Ca}^{2+}$ signals with no apparent failures even in the most distant parallel 
A
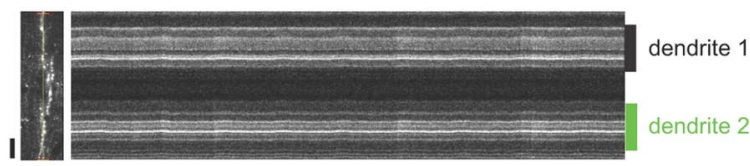

B
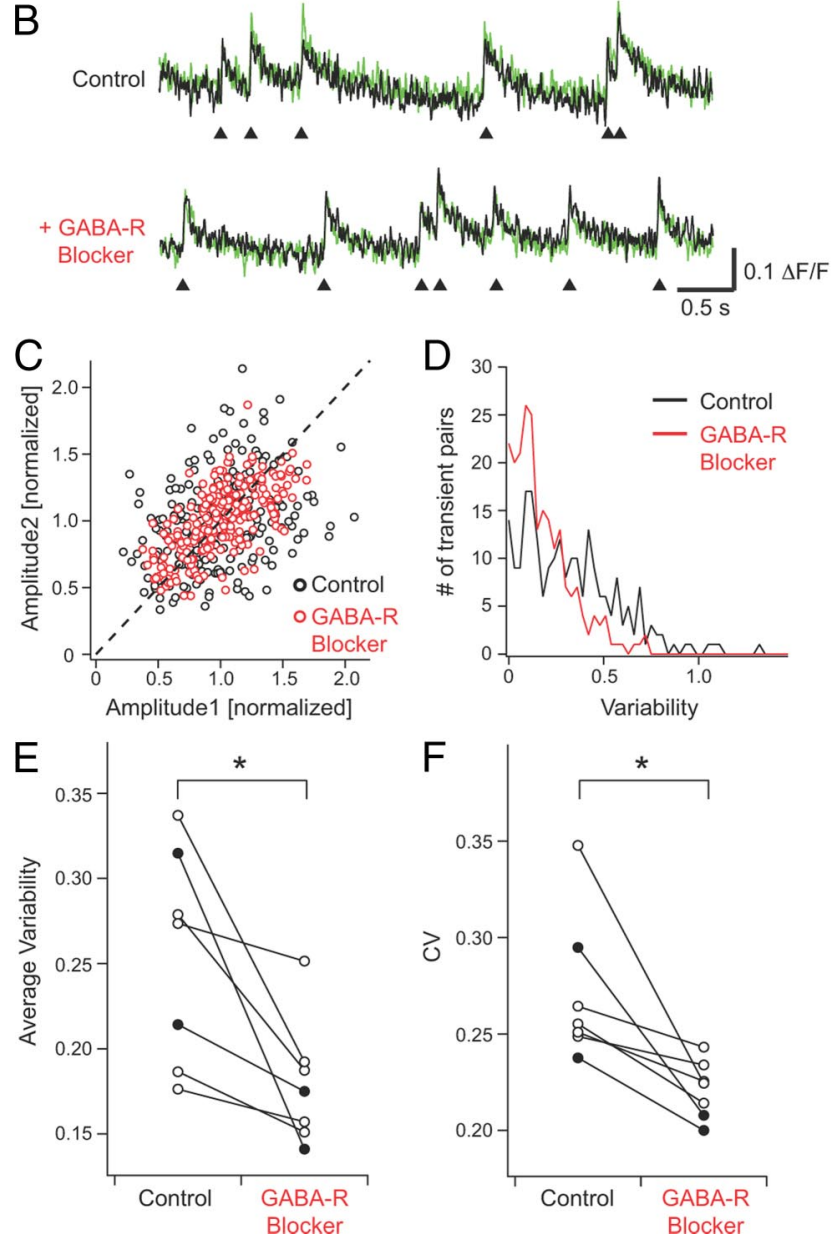

Figure 8. Variability of the $\mathrm{CF}$-triggered $\left[\mathrm{Ca}^{2+}\right]$ transients in distal dendrites is controlled by GABAergic synaptic inputs. $\boldsymbol{A},\left[\mathrm{Ca}^{2+}\right]$ transients in different dendritic branches were measured at $\sim 100 \mu \mathrm{m}$ from soma (top left, yellow line) in line scan mode across the whole dendritic width of a Purkinje cell (0.2 mM 0GB-1). Two dendritic regions were selected for analysis. Scale bar, $20 \mu \mathrm{m} . \boldsymbol{B}$, Top, $\left[\mathrm{Ca}^{2+}\right]$ transients in the two dendritic regions corresponding to the line scan image shown in $\boldsymbol{A}$. Green and black traces show simultaneous fluorescence changes in the regions indicated in line scan image. Arrowheads indicate the occurrence of CS. Bottom, $\left[\mathrm{Ca}^{2+}\right]$ transients in the same region in the presence of SR95531 (50 $\mu \mathrm{M})$ and CGP52432 (50 $\mu \mathrm{M})$. Note that the difference in the peak amplitude of $\left[\mathrm{Ca}^{2+}\right]$ transients between the two dendrites is less variable in the presence of the blocker of GABAergic inputs. $C$, Representative scatter plot of peak amplitude in different dendrites. The data are normalized to the average. $\boldsymbol{D}$, Histogram of variability calculated from the data in $C$. Distribution was skewed to smaller value in the presence of GABA blockers. $E$, Average variability of the peak amplitude of $\left[\mathrm{Ca}^{2+}\right]$ transients between different branches before (Control) and after the application of GABA blockers (GABA-R Blocker). Open and closed circles show the data in up and down states, respectively ( $n=5$ cells, $\left.{ }^{*} p=0.019\right)$. $\boldsymbol{F}$, Change in the coefficient of variation in the peak amplitude in the same dendrites. Application of GABA blockers significantly reduced the variability within individual dendrites $\left(n=5\right.$ cells, $\left.{ }^{*} p=0.016\right)$.

fiber spines on spiny branchlets. These spiny branchlets are far from the location of CF synaptic input onto proximal dendrites of Purkinje cells (Palay and Chan-Palay, 1974), suggesting that the proximal CF input reliably evokes regenerative $\mathrm{Ca}^{2+}$ spikes that propagate effectively throughout the entire dendritic tree. Thus, the CF-evoked dendritic $\left[\mathrm{Ca}^{2+}\right]$ rise represents a global signal even under in vivo conditions. The unusual dendritic ge- ometry of the Purkinje cell, with large-caliber primary dendrites connected to short terminal segments, may facilitate the effective spread of regenerative potentials into the terminal dendrites of Purkinje cells (Vetter et al., 2001), thus maximizing the global nature of the dendritic $\mathrm{Ca}^{2+}$ signal.

\section{Modulation of dendritic $\mathrm{Ca}^{2+}$ signals}

The CF-triggered $\mathrm{Ca}^{2+}$ signals recorded at a given dendritic location were not constant but could be modulated depending on the membrane potential of the Purkinje cell. We demonstrated that the underlying mechanism of the voltage dependence of the dendritic $\mathrm{Ca}^{2+}$ signals is by gating the number of dendritic $\mathrm{Ca}^{2+}$ spikes associated with the CF response, which in turn may be caused by voltage-dependent recruitment of dendritic $\mathrm{Ca}^{2+}$ channels or voltage-dependent inactivation of $\mathrm{K}^{+}$channels (Miyakawa et al., 1992; Midtgaard et al., 1993). This parallels the changes in CS waveform observed at the soma depending on membrane potential state (Tal et al., 2008). These findings indicate that the global dendritic $\mathrm{Ca}^{2+}$ signal triggered by the $\mathrm{CF}$ event is not a unitary all-or-none event but rather is modulatable depending on the membrane potential of the cell and the synaptic inputs it receives in vivo. The source of this modulation can be the intrinsic bistability of the Purkinje cell (Williams et al., 2002; Loewenstein et al., 2005; Fernandez et al., 2007; McKay et al., 2007) (cf. Schonewille et al., 2006), which we demonstrate can determine distinct levels of dendritic $\mathrm{Ca}^{2+}$ signal. Alternatively, graded levels of $\mathrm{Ca}^{2+}$ signal could be provided by different levels of background parallel fiber excitatory synaptic input.

CF input can itself trigger the transitions between up and down states in Purkinje cells (Loewenstein et al., 2005; Fernandez et al., 2007; McKay et al., 2007). Our observation that the $\left[\mathrm{Ca}^{2+}\right]$ transients associated with the CF inputs that triggered the transition from the firing up state to the silent down state were larger than those associated with $\mathrm{CF}$ inputs that did not trigger transitions suggests that the larger $\mathrm{Ca}^{2+}$ influx may play a role in regulating transitions from the up state to the down state. This is consistent with work in slice preparations showing that $\mathrm{Ca}^{2+}$ dependent $\mathrm{K}^{+}$current is activated by the CS (Hounsgaard and Midtgaard, 1989) and that blocking of $\mathrm{Ca}^{2+}$-dependent $\mathrm{K}^{+}$ channels prevents the transition from up to down state triggered by CF input (McKay et al., 2007). On the other hand, the correlation between CF-triggered $\mathrm{Ca}^{2+}$ influx and state transitions represents an apparent contrast with in vitro data, showing that prolonged intracellular dialysis with $20 \mathrm{~mm}$ BAPTA enhances bistable behavior of the Purkinje cell (Williams et al., 2002). However, bistability caused by continuous blockade of $\mathrm{Ca}^{2+}$ dependent $\mathrm{K}^{+}$currents by BAPTA perfusion leads to spontaneous state transitions that are not linked to CF input, with the up state being associated with a very high-frequency burst of SSs that rapidly inactivates. These are very different features from the behavior observed in vivo, and thus CF-triggered state transitions in vivo are likely to be different from spontaneous transitions associated with BAPTA injection in vitro. In addition, our data showing similar state-dependent changes in $\left[\mathrm{Ca}^{2+}\right]$ transients under light anesthesia appear to be inconsistent with the lower prevalence of bistability in awake mice (Schonewille et al., 2006). Although this issue is still debated (Loewenstein et al., 2005; Schonewille et al., 2006; Tal et al., 2008; Rokni et al., 2009; Yartsev et al., 2009), one possible explanation is that increased background and evoked parallel fiber input in the awake state could override the hyperpolarization that represents the transition from up to down state. In that case, we would expect bistability to be modulated by wakefulness and not by anesthetic level. In other 
words, different levels of anesthesia may display similar levels of bistability.

Using simultaneous high-speed imaging at different locations in the dendritic tree, we also demonstrated that there is variability in $\mathrm{Ca}^{2+}$ influx across the dendritic tree during a given CF input, which can also fluctuate from trial to trial. We show that this location-dependent variability is controlled by the level of GABAergic synaptic input to the Purkinje cell. Previous work in cerebellar slices has shown that GABAergic synaptic input can provide local regulation of the magnitude of dendritic $\mathrm{Ca}^{2+}$ signals driven by $\mathrm{CF}$ input (Callaway et al., 1995). Our findings confirm the physiological relevance of these results in vivo and suggest that the intersite and intrasite variability in $\mathrm{Ca}^{2+}$ signals may result in part from differential activity in local GABAergic interneurons projecting to different regions of the Purkinje cell dendritic tree with different timing to CF inputs. The contribution of GABAergic inputs to the variability between and within dendrites in vivo is somewhat smaller than was observed in slice (60\% suppression at maximum) (Callaway et al., 1995, their Fig. 5A). This difference is probably attributable to the synchronous activation of interneuron axons in vitro; the narrow time window for the effective suppression of $\mathrm{Ca}^{2+}$ influx by inhibition $( \pm 4 \mathrm{~ms}$ ) (Callaway et al., 1995) combined with the relatively low in vivo spontaneous firing rate of molecular layer interneurons $(<10 \mathrm{~Hz})$ (Loewenstein et al., 2005) and CS $(\sim 1 \mathrm{~Hz})$ should reduce the net effect of inhibition in vivo compared to the in vitro measurement.

Interestingly, the dendritic $\mathrm{Ca}^{2+}$ signals evoked by sensory-driven CF input were indistinguishable from spontaneous CF input, which implies that the background synaptic input driven by the sensory stimulus did not substantially alter the CF-driven response. This result also implies that the sensory inputs provided by inferior olive neurons through CFs rely on their precise timing and the spatiotemporal activation patterns in the local population of Purkinje cells (Llinás and Sasaki, 1989; Sasaki et al., 1989; Ozden et al., 2009; Schultz et al., 2009) in order for them to be discriminated from spontaneous $\mathrm{CF}$ input.

\section{Functional implications}

The widespread, reliable nature of the spontaneous and sensoryevoked $\mathrm{Ca}^{2+}$ signals triggered by CF inputs to Purkinje cell observed here directly confirms the idea that CF input provides a global associative signal for the integration of parallel fiber inputs and synaptic plasticity at parallel fiber synapses (Ito, 1984). However, this signal is modulatable depending on the state of the cell and potentially also on the level of background excitatory synaptic input. Furthermore, the ability of synaptic inhibition to mod-
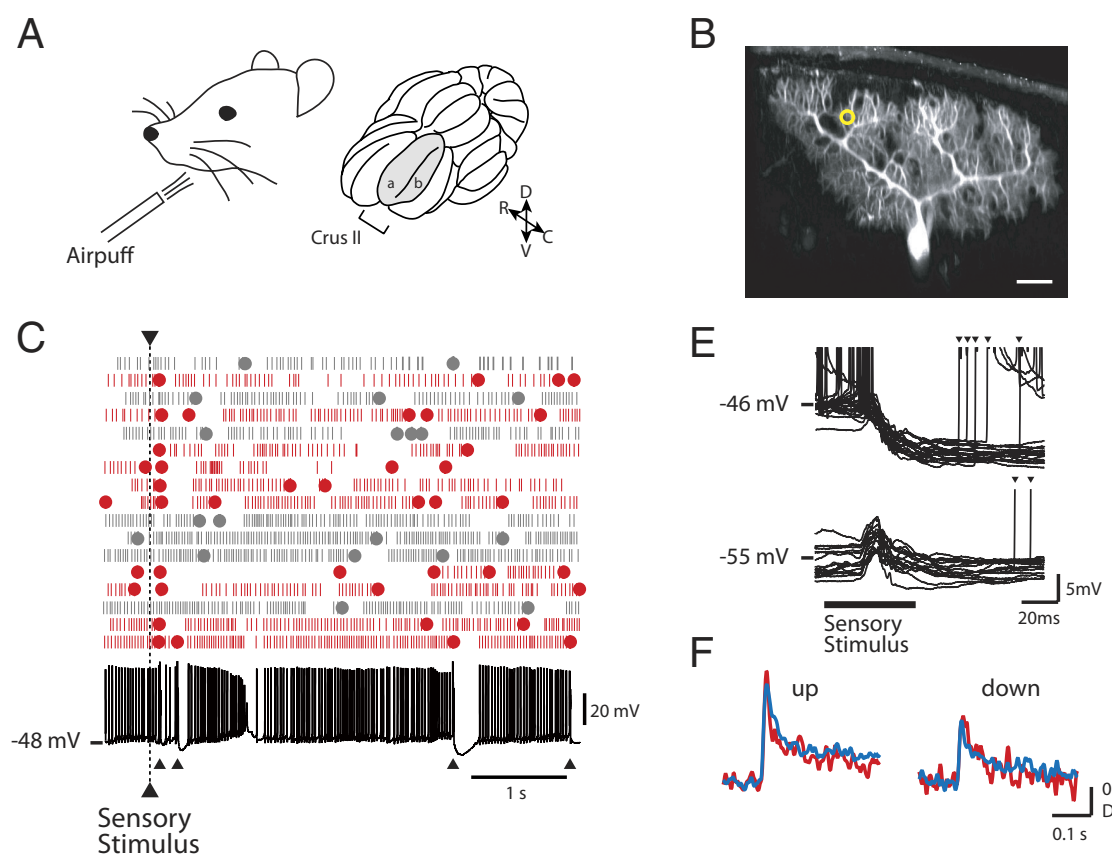

F
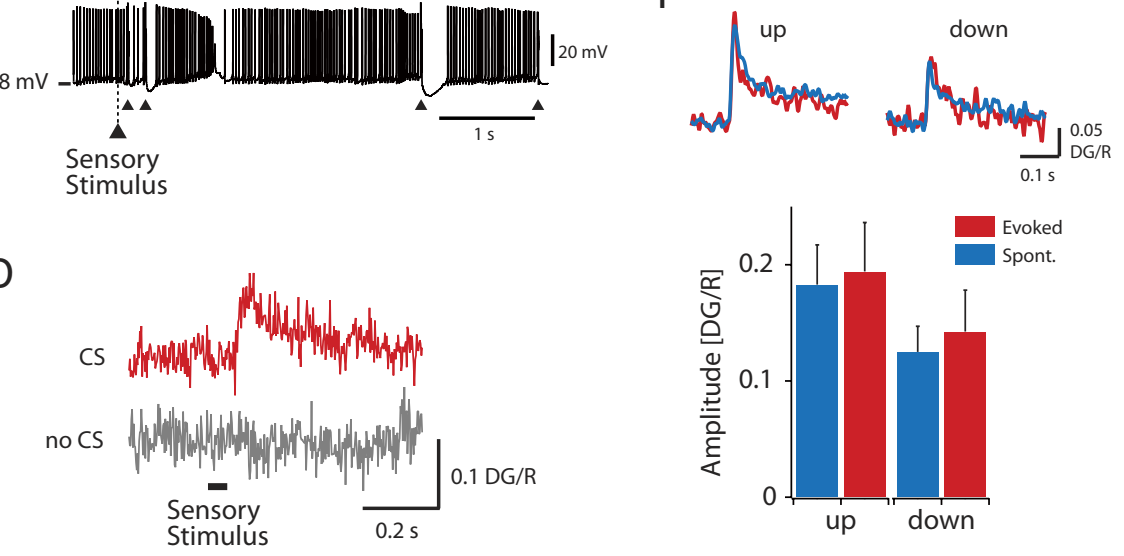

Figure 9. Sensory-evoked $\mathrm{CF}$ input triggers robust $\left[\mathrm{Ca}^{2+}\right]$ transients in dendrites. $A$, Configuration of the experiment Left, A brief airpuff stimulus ( $40-60 \mathrm{psi}, 50 \mathrm{~ms}$ ) was delivered to the ipsilateral perioral surface (upper lip or vibrissae). Right, A whole-cell patch-clamp recording was made in the folium Crus lla of the left hemisphere. $\boldsymbol{B}$, Projection image of the cell and the position of the line scan (yellow circle, $\sim 130 \mu \mathrm{m}$ from soma) for the data shown in $\boldsymbol{C}-\boldsymbol{F}$. Whole-cell SS (lines). Ten of seventeen consecutive trials contained evoked CS (red) while others did not (gray). D, Average $\left[\mathrm{Ca}^{2+}\right]$ transients with (red) and without (gray) evoked CS measured at the location shown in $\boldsymbol{B} \cdot\left[\mathrm{Ca}^{2+}\right]$ transients were aligned of the stimulus (Stim.) and averaged across the trials. Note that the slow rising $\left[\mathrm{Ca}^{2+}\right]$ increase, compared with the averaged trace aligned to the onset of $\mathrm{CS}$ (e. g., $\boldsymbol{F}$ ), is due to the fluctuations in the latency of CS to the onset of the stimulus. $\boldsymbol{E}$, Representative responses of a Purkinje cell to sensory-evoked parallel fiber and CF (arrowhead) inputs in the state (top) and hyperpolarized down state (bottom). $\boldsymbol{F}$, Top traces, overlay of sensory-evoked (red) and spontaneous (blue) $\left[\mathrm{Ca}^{2+}\right]$ transients in the up state (left) and the down state (right). Bottom, Comparison of sensoryfred (red bars) and spontaneous (blue bars) $\left[\mathrm{Ca}^{2+}\right]$ transients in dendrites ( 9 dendritic locations in 3 cells, 50-170 $\mu \mathrm{m}$ from soma). There is no significant difference between evoked and spontaneous (Spont.) transients ( $p=0.14$, two-way ANOVA), but there is a significant difference between the transients recorded in up and down states $(p=0.036)$.

ulate the $\mathrm{Ca}^{2+}$ signal provides a mechanism for synaptic integration and plasticity to be gated individually in different dendritic branches of the same Purkinje cell.

The interaction between parallel fiber and CF inputs triggers nonlinear $\left[\mathrm{Ca}^{2+}\right]$ signals in single dendritic branchlets in vitro, associated with the induction of short-term or longterm plasticity at parallel fiber to Purkinje cell synapses (Wang et al., 2000; Brenowitz and Regehr, 2005). Our in vivo recordings revealed sensory-evoked concurrent activation of parallel fiber and CF inputs (Fig. 9E), and thus one might expect that nonlinear $\left[\mathrm{Ca}^{2+}\right]$ rises at the active parallel fiber synapses in vivo, as observed in vitro. Further refinement of our experimental approach, including higher sensitivity $\left[\mathrm{Ca}^{2+}\right]$ imaging and rapid scanning techniques (Jia et al., 2010), may ultimately allow one to search for and detect the interaction be- 
tween parallel and climbing fiber inputs at the single synapse level in vivo.

\section{References}

Bekkers JM, Häusser M (2007) Targeted dendrotomy reveals active and passive contributions of the dendritic tree to synaptic integration and neuronal output. Proc Natl Acad Sci U S A 104:11447-11452.

Bower JM, Woolston DC (1983) Congruence of spatial organization of tactile projections to granule cell and Purkinje cell layers of cerebellar hemispheres of the albino rat: vertical organization of cerebellar cortex. J Neurophysiol 49:745-766.

Brenowitz SD, Regehr WG (2005) Associative short-term synaptic plasticity mediated by endocannabinoids. Neuron 45:419-431.

Broser PJ, Schulte R, Lang S, Roth A, Helmchen F, Waters J, Sakmann B, Wittum G (2004) Nonlinear anisotropic diffusion filtering of threedimensional image data from two-photon microscopy. J Biomed Opt 9:1253-1264.

Brown IE, Bower JM (2001) Congruence of mossy fiber and climbing fiber tactile projections in the lateral hemispheres of the rat cerebellum. J Comp Neurol 429:59-70.

Callaway JC, Lasser-Ross N, Ross WN (1995) IPSPs strongly inhibit climbing fiber-activated $\left[\mathrm{Ca}^{2+}\right] \mathrm{i}$ increases in the dendrites of cerebellar Purkinje neurons. J Neurosci 15:2777-2787.

Chan CY, Hounsgaard J, Midtgaard J (1989) Excitatory synaptic responses in turtle cerebellar Purkinje cells. J Physiol 409:143-156.

Chen X, Kovalchuk Y, Adelsberger H, Henning HA, Sausbier M, Wietzorrek G, Ruth P, Yarom Y, Konnerth A (2010) Disruption of the olivocerebellar circuit by Purkinje neuron-specific ablation of BK channels. Proc Natl Acad Sci U S A 107:12323-12328.

Coesmans M, Weber JT, De Zeeuw CI, Hansel C (2004) Bidirectional parallel fiber plasticity in the cerebellum under climbing fiber control. Neuron 44:691-700.

Davie JT, Clark BA, Häusser M (2008) The origin of the complex spike in cerebellar Purkinje cells. J Neurosci 28:7599-7609.

Denk W, Strickler JH, Webb WW (1990) Two-photon laser scanning fluorescence microscopy. Science 248:73-76.

Denk W, Sugimori M, Llinás R (1995) Two types of calcium response limited to single spines in cerebellar Purkinje cells. Proc Natl Acad Sci U S A 92:8279-8282.

Dzubay JA, Otis TS (2002) Climbing fiber activation of metabotropic glutamate receptors on cerebellar Purkinje neurons. Neuron 36:1159-1167.

Eilers J, Augustine GJ, Konnerth A (1995) Subthreshold synaptic $\mathrm{Ca}^{2+}$ signalling in fine dendrites and spines of cerebellar Purkinje neurons. Nature 373:155-158.

Fernandez FR, Engbers JD, Turner RW (2007) Firing dynamics of cerebellar Purkinje cells. J Neurophysiol 98:278-294.

Fujita Y (1968) Activity of dendrites of single Purkinje cells and its relationship to so-called inactivation response in rabbit cerebellum. J Neurophysiol 31:131-141.

Hansel C, Linden DJ (2000) Long-term depression of the cerebellar climbing fiber-Purkinje neuron synapse. Neuron 26:473-482.

Hartell NA (1996) Strong activation of parallel fibers produces localized calcium transients and a form of LTD that spreads to distant synapses. Neuron 16:601-610.

Häusser M, Clark BA (1997) Tonic synaptic inhibition modulates neuronal output pattern and spatiotemporal synaptic integration. Neuron 19:665-678.

Helmchen F, Svoboda K, Denk W, Tank DW (1999) In vivo dendritic calcium dynamics in deep-layer cortical pyramidal neurons. Nat Neurosci 2:989-996.

Holt GR, Softky WR, Koch C, Douglas RJ (1996) Comparison of discharge variability in vitro and in vivo in cat visual cortex neurons. J Neurophysiol 75:1806-1814.

Hounsgaard J, Midtgaard J (1989) Synaptic control of excitability in turtle cerebellar Purkinje cells. J Physiol 409:157-170.

Hounsgaard J, Yamamoto C (1979) Dendritic spikes in Purkinje cells of the guinea pig cerebellum studied in vitro. Exp Brain Res 37:387-398.

Isope P, Murphy TH (2005) Low threshold calcium currents in rat cerebellar Purkinje cell dendritic spines are mediated by T-type calcium channels. J Physiol 562:257-269.

Ito M (1984) The cerebellum and neural control. New York: Raven.

Jaeger D, Bower JM (1994) Prolonged responses in rat cerebellar Purkinje cells following activation of the granule cell layer: an intracellular in vitro and in vivo investigation. Exp Brain Res 100:200-214.

Jia H, Rochefort NL, Chen X, Konnerth A (2010) Dendritic organization of sensory input to cortical neurons in vivo. Nature 464:1307-1312.

Kitamura K, Judkewitz B, Kano M, Denk W, Häusser M (2008) Targeted patch-clamp recordings and single-cell electroporation of unlabeled neurons in vivo. Nat Methods 5:61-67.

Konnerth A, Dreessen J, Augustine GJ (1992) Brief dendritic calcium signals initiate long-lasting synaptic depression in cerebellar Purkinje cells. Proc Natl Acad Sci U S A 89:7051-7055.

Kulik A, Nakadate K, Hagiwara A, Fukazawa Y, Luján R, Saito H, Suzuki N, Futatsugi A, Mikoshiba K, Frotscher M, Shigemoto R (2004) Immunocytochemical localization of the alpha $1 \mathrm{~A}$ subunit of the P/Q-type calcium channel in the rat cerebellum. Eur J Neurosci 19:2169-2178.

Lev-Ram V, Miyakawa H, Lasser-Ross N, Ross WN (1992) Calcium transients in cerebellar Purkinje neurons evoked by intracellular stimulation. J Neurophysiol 68:1167-1177.

Llinás R, Sasaki K (1989) The functional organization of the olivo-cerebellar system as examined by multiple Purkinje cell recordings. Eur J Neurosci 1:587-602.

Llinás R, Sugimori M (1980a) Electrophysiological properties of in vitro Purkinje cell somata in mammalian cerebellar slices. J Physiol 305:171-195.

Llinás R, Sugimori M (1980b) Electrophysiological properties of in vitro Purkinje cell dendrites in mammalian cerebellar slices. J Physiol 305:197-213.

Loewenstein Y, Mahon S, Chadderton P, Kitamura K, Sompolinsky H, Yarom Y, Häusser M (2005) Bistability of cerebellar Purkinje cells modulated by sensory stimulation. Nat Neurosci 8:202-211.

Maeda H, Ellis-Davies GC, Ito K, Miyashita Y, Kasai H (1999) Supralinear $\mathrm{Ca}^{2+}$ signaling by cooperative and mobile $\mathrm{Ca}^{2+}$ buffering in Purkinje neurons. Neuron 24:989-1002.

Margrie TW, Brecht M, Sakmann B (2002) In vivo, low-resistance, wholecell recordings from neurons in the anaesthetized and awake mammalian brain. Pflugers Arch 444:491-498.

McKay BE, Turner RW (2004) $\mathrm{K}_{\mathrm{v}} 3 \mathrm{~K}^{+}$channels enable burst output in rat cerebellar Purkinje cells. Eur J Neurosci 20:729-739.

McKay BE, Engbers JD, Mehaffey WH, Gordon GR, Molineux ML, Bains JS, Turner RW (2007) Climbing fiber discharge regulates cerebellar functions by controlling the intrinsic characteristics of Purkinje cell output. J Neurophysiol 97:2590-2604.

Midtgaard J, Lasser-Ross N, Ross WN (1993) Spatial distribution of $\mathrm{Ca}^{2+}$ influx in turtle Purkinje cell dendrites in vitro: role of a transient outward current. J Neurophysiol 70:2455-2469.

Miyakawa H, Lev-Ram V, Lasser-Ross N, Ross WN (1992) Calcium transients evoked by climbing fiber and parallel fiber synaptic inputs in guinea pig cerebellar Purkinje neurons. J Neurophysiol 68:1178-1189.

Miyashita Y, Nagao S (1984) Contribution of cerebellar intracortical inhibition to Purkinje cell response during vestibulo-ocular reflex of alert rabbits. J Physiol 351:251-262.

Miyata M, Finch EA, Khiroug L, Hashimoto K, Hayasaka S, Oda SI, Inouye M, Takagishi Y, Augustine GJ, Kano M (2000) Local calcium release in dendritic spines required for long-term synaptic depression. Neuron 28:233-244

Mukamel EA, Nimmerjahn A, Schnitzer MJ (2009) Automated analysis of cellular signals from large-scale calcium imaging data. Neuron 63: $747-760$.

Murayama M, Pérez-Garci E, Nevian T, Bock T, Senn W, Larkum ME (2009) Dendritic encoding of sensory stimuli controlled by deep cortical interneurons. Nature 457:1137-1141.

Nevian T, Helmchen F (2007) Calcium indicator loading of neurons using single-cell electroporation. Pflugers Arch 454:675-688.

Ozden I, Sullivan MR, Lee HM, Wang SS (2009) Reliable coding emerges from coactivation of climbing fibers in microbands of cerebellar Purkinje neurons. J Neurosci 29:10463-10473.

Palay S, Chan-Palay V (1974) Cerebellar cortex: cytology and organization. New York: Springer.

Palmer LM, Clark BA, Grundemann J, Roth A, Stuart G, Häusser M (2010) Initiation of simple and complex spikes in cerebellar Purkinje cells. J Physiol 588:1709-1717.

Pologruto TA, Sabatini BL, Svoboda K (2003) ScanImage: flexible software for operating laser scanning microscopes. Biomed Eng Online 2:13.

Rancz EA, Häusser M (2006) Dendritic calcium spikes are tunable triggers 
of cannabinoid release and short-term synaptic plasticity in cerebellar Purkinje neurons. J Neurosci 26:5428-5437.

Rokni D, Tal Z, Byk H, Yarom Y (2009) Regularity, variability and bi-stability in the activity of cerebellar Purkinje cells. Front Cell Neurosci 3:12.

Sakurai M (1990) Calcium is an intracellular mediator of the climbing fiber in induction of cerebellar long-term depression. Proc Natl Acad Sci U S A 87:3383-3385.

Sasaki K, Bower JM, Llinás R (1989) Multiple Purkinje cell recording in rodent cerebellar cortex. Eur J Neurosci 1:572-586.

Schonewille M, Khosrovani S, Winkelman BH, Hoebeek FE, De Jeu MT, Larsen IM, Van der Burg J, Schmolesky MT, Frens MA, De Zeeuw CI (2006) Purkinje cells in awake behaving animals operate at the upstate membrane potential. Nat Neurosci 9:459-461; author reply 461.

Schultz SR, Kitamura K, Post-Uiterweer A, Krupic J, Häusser M (2009) Spatial pattern coding of sensory information by climbing fiber-evoked calcium signals in networks of neighboring cerebellar Purkinje cells. J Neurosci 29:8005-8015.

Stuart G, Häusser M (1994) Initiation and spread of sodium action potentials in cerebellar Purkinje cells. Neuron 13:703-712.

Sullivan MR, Nimmerjahn A, Sarkisov DV, Helmchen F, Wang SS (2005) In vivo calcium imaging of circuit activity in cerebellar cortex. J Neurophysiol 94:1636-1644.

Svoboda K, Denk W, Kleinfeld D, Tank DW (1997) In vivo dendritic calcium dynamics in neocortical pyramidal neurons. Nature 385:161-165.

Svoboda K, Helmchen F, Denk W, Tank DW (1999) Spread of dendritic excitation in layer $2 / 3$ pyramidal neurons in rat barrel cortex in vivo. Nat Neurosci 2:65-73.
Takechi H, Eilers J, Konnerth A (1998) A new class of synaptic response involving calcium release in dendritic spines. Nature 396:757-760.

Tal Z, Chorev E, Yarom Y (2008) State-dependent modification of complex spike waveforms in the cerebellar cortex. Cerebellum 7:577-582.

Tank DW, Sugimori M, Connor JA, Llinás RR (1988) Spatially resolved calcium dynamics of mammalian Purkinje cells in cerebellar slice. Science 242:773-777.

Vetter P, Roth A, Häusser M (2001) Propagation of action potentials in dendrites depends on dendritic morphology. J Neurophysiol 85:926-937.

Wang SS, Denk W, Häusser M (2000) Coincidence detection in single dendritic spines mediated by calcium release. Nat Neurosci 3:1266-1273.

Waters J, Helmchen F (2004) Boosting of action potential backpropagation by neocortical network activity in vivo. J Neurosci 24:11127-11136.

Waters J, Larkum M, Sakmann B, Helmchen F (2003) Supralinear $\mathrm{Ca}^{2+}$ influx into dendritic tufts of layer $2 / 3$ neocortical pyramidal neurons in vitro and in vivo. J Neurosci 23:8558-8567.

Weber JT, De Zeeuw CI, Linden DJ, Hansel C (2003) Long-term depression of climbing fiber-evoked calcium transients in Purkinje cell dendrites. Proc Natl Acad Sci U S A 100:2878-2883.

Williams SR, Christensen SR, Stuart GJ, Häusser M (2002) Membrane potential bistability is controlled by the hyperpolarization-activated current $\mathrm{I}(\mathrm{H})$ in rat cerebellar Purkinje neurons in vitro. J Physiol 539:469-483.

Yartsev MM, Givon-Mayo R, Maller M, Donchin O (2009) Pausing Purkinje cells in the cerebellum of the awake cat. Front Syst Neurosci 3:2.

Yasuda R, Sabatini BL, Svoboda K (2003) Plasticity of calcium channels in dendritic spines. Nat Neurosci 6:948-955. 